\title{
Sevoflurane: Practice Change Integration Quality Improvement for Pharmacoeconomic Accountability
}

Kelly Moore Meyers

West Virginia University, kellylirg@gmail.com

Follow this and additional works at: https://researchrepository.wvu.edu/etd

Part of the Anesthesiology Commons

\section{Recommended Citation}

Meyers, Kelly Moore, "Sevoflurane: Practice Change Integration Quality Improvement for Pharmacoeconomic Accountability" (2021). Graduate Theses, Dissertations, and Problem Reports. 10231.

https://researchrepository.wvu.edu/etd/10231

This Problem/Project Report is protected by copyright and/or related rights. It has been brought to you by the The Research Repository @WVU with permission from the rights-holder(s). You are free to use this Problem/Project Report in any way that is permitted by the copyright and related rights legislation that applies to your use. For other uses you must obtain permission from the rights-holder(s) directly, unless additional rights are indicated by a Creative Commons license in the record and/ or on the work itself. This Problem/Project Report has been accepted for inclusion in WVU Graduate Theses, Dissertations, and Problem Reports collection by an authorized administrator of The Research Repository @ WVU. For more information, please contact researchrepository@mail.wvu.edu. 
Sevoflurane: Practice Change Integration

Quality Improvement for Pharmacoeconomic Accountability

Kelly M. Meyers

DNP Project Manuscript submitted

to the School of Nursing

at West Virginia University

In partial fulfillment of the requirements for the degree of

Doctor of Nursing Practice

Sandra Cotton, D.N.P., Chair

Kesheng Wang, Ph.D.

Eric Lindstrom, M.H.S., C.R.N.A.

Department of Nursing

Morgantown, West Virginia

2021

Keywords: sevoflurane, fresh gas flows, induction, maintenance, educational intervention, pharmacoeconomic, sustainability

Copyright 2021 Kelly Moore Meyers 


\section{Abstract \\ Sevoflurane: Practice Change Integration Quality Improvement for Pharmacoeconomic Accountability}

\section{Kelly M. Meyers}

Background: Pharmacoeconomic accountability is increasingly of concern to patients, institutions, and healthcare payors alike. Annual sevoflurane expenditure at a large university hospital exceeds $\$ 300,000$ (personal communication, Eric Likar). Sevoflurane is a liquid, volatile anesthetic delivered from a vaporizer, through a breathing circuit to a patient. Multiple studies focused on reducing sevoflurane use note significant cost savings were attained with a variety of techniques. Moreover, using less sevoflurane reduces the environmental impact of volatile agents which are potent greenhouse gases. Through simple interventions, such as a brief staff education and reminders, Lethbridge et al. (2007) demonstrated over a fifty-percent reduction in sevoflurane use. At the beginning of a case and during the surgical or maintenance phase of anesthesia, vaporized sevoflurane induces and maintains unconsciousness in the patient.

Objective: The project aims were to increase provider knowledge, attitude, and skills to decrease expenditures on sevoflurane in an anesthesia department at a large university hospital.

Methods: An educational presentation, highlighting the potential benefits of using reduced fresh gas flows to deliver sevoflurane, was given to all anesthesia providers at a large university hospital. Lewins' Change Theory provided the scientific underpinning for the educational intervention about sevoflurane providing information to motivate anesthesia providers to change their practice. The educational program was followed by academic detailing throughout the study period to reinforce the goal of lowering sevoflurane average fresh gas flows. Data collection focused on provider knowledge and attitude using a pre/post education survey. Before and after survey responses were analyzed using a paired t-test. Review of a convenience sample of 300 consecutive same-day-surgery pediatric cases, that used sevoflurane for induction and maintenance of anesthesia, separated into three groups of 100 cases each. These sets-baseline and 1 month and 3 months-were compared for average fresh gas flow, procedure length, and minutes to airway and analyzed using ANOVA and Tukey's test.

Results: Provider knowledge and attitude measured using a Likert scale increased across all providers. Average fresh gas flow use decreased with each consecutive group and reached statistical significance at month 3 , with a decrease in average fresh gas flows of $15 \%$.

Discussion: Excess sevoflurane is carried into a waste gas system where it is exhausted into the environment. Fresh gases used to deliver sevoflurane are frequently higher than necessary and increase the production of sevoflurane as a waste anesthesia gas. The opportunity for reducing sevoflurane use and institutional expenditure on sevoflurane exists while increasing sustainability.

Conclusion: An educational intervention increased anesthesia provider knowledge, attitude, and skill regarding the use of sevoflurane for the induction and maintenance of anesthesia in a pediatric sameday-surgery population. Reducing sevoflurane use can improve pharmacoeconomic targets and ultimately reduce the environmental impact of potent greenhouse gases.

Keywords: sevoflurane, fresh gas flows, induction, maintenance, educational intervention, pharmacoeconomic, sustainability. 


\section{Dedication}

I dedicate this work to the many children who receive care at West Virginia University Hospital and their families. Through efforts like these, we may provide an environment where climate change is an obstacle overcome, and our children see a brighter future with a healthier planet. 


\section{Acknowledgements}

Only through the dedicated work and experience of those before me, have I found the support and guidance to undertake this project. Many thanks to my colleagues who have provided ideas and inspiration as I have moved through the many steps in accomplishing this project. There have been many who have served as role-models and provided encouragement including David Rosen, Pavithra Ellison, Sarah Hinnant, Jennifer Sieber, and my mother, Sue Moore. A special thank you to Dr. Sandra Cotton for supporting me for the entirety of this project and helping me grow personally and professionally. Your guidance and advice were unparalleled throughout my time as a DNP student. Thank you to my committee members, Dr. Kesheng Wang and Jake Lindstrom, and others-Eric Likar, Kathi Trickett, and Dr. Piamjariyakul Ubolrat who helped me navigate uncharted scholarly territory to see this manuscript to completion.

Finally, thank you to my two sweet children, for whom without their support, patience, cooperation, and love, I would have never completed this. 


\section{Table of Contents}

Abstract

Dedication

Acknowledgements

iv

Table of Contents

v

Index of Appendices

vii

List of Tables

viii

List of Figures

ix

Introduction

Problem Description

Available Knowledge

Literature Review and Synthesis

Rationale

PICO Question

Theoretical Framework

Methods

Needs Assessment

Intervention, Context, and Population

SWOT Analysis

Project Design, SMART Workplan, and Financial Considerations

Outcomes

Analysis

Ethical Considerations

Results

Aim 1 
Aim 2

Discussion

Summary

23

Interpretation

26

Limitations

26

Conclusion

28

References 
Index of Appendices

Appendix A

Appendix B

Appendix C

Appendix D

Appendix E
Educational Program and Pre/Post Educational Survey

55

Data Collection Tool

Project Support

IRB Approval

Evaluation Plan
63

64

65

67 


\section{List of Tables}

$\begin{array}{lll}\text { Table } 1 & \text { Sevoflurane EBP Administration } & 34\end{array}$

Table 2 Descriptive Statistics Procedure Length, Average FGF, Minutes to Airway 39

Table $3 \quad$ Survey Demographic Data: Provider Type \& Years of Experience $\quad 40$

Table $4 \quad$ Before and After Survey response Statistical Comparison $\quad 41$

Table 5 ANOVA Summary Procedure Length, Average FGF, \& Minutes to Airway 43

Table $6 \quad$ Tukey's Test for Procedure Length, Minutes to Airway, \& Average FGF $\quad 44$ 


\section{List of Figures}

$\begin{array}{lll}\text { Figure } 1 & \text { Projected Project Timeline } & 45\end{array}$

$\begin{array}{lll}\text { Figure } 2 & \text { Adjusted Project Timeline } & 46\end{array}$

Figure $3 \quad$ Summary of Survey Responses: Knowledge of Sevoflurane and Pollution $\quad 47$

Figure $4 \quad$ Summary of Survey Responses: Knowledge of Sevoflurane and FGF 48

Figure $5 \quad$ Summary of Survey Responses: Willingness to Integrate Evidence 49

Figure $6 \quad$ Summary of Survey Responses: Willingness to Decrease Pollution 50

Figure $7 \quad$ Summary of Survey Responses: Willingness to Decrease Costs 51

Figure $8 \quad$ Graphic of Minutes to Airway $\quad 52$

Figure $9 \quad$ Graphic of Average Fresh Gas Flow 53

Figure $10 \quad$ Graphic of Procedure Length 54 


\section{Sevoflurane: Practice Change Integration}

\section{Quality Improvement for Pharmacoeconomic Accountability}

\section{Introduction}

Cost conscientiousness is a pressing issue in healthcare in general as US healthcare expenditures have continued to climb for many years. According to the leadership in the anesthesia department at the hospital of interest, huge financial losses reaching over forty million dollars have occurred so far during the coronavirus pandemic. Capital budget purchases in the anesthesia department were indefinitely on hold as the pandemic unfolded. The support of the chief anesthetist was gained by detailing the proposed project and potential financial savings. Similarly, support from the operating room pharmacy director, and the coordinator of internet technology management (IT) for the anesthesia department were obtained, as well as buy-in from leadership in the department of anesthesiology. To facilitate evidence-based practice (EBP) change, a comprehensive approach that involves stakeholders at all levels of planning is essential.

\section{Problem Description}

Sevoflurane is a volatile anesthetic agent widely used in the delivery of anesthesia. Lethbridge et al. (2007) documented its rising popularity in anesthesia. The authors noted a $42 \%$ increase in use worldwide and a $55 \%$ increase in the US over a four-year period. The safe, rapid on and offset have given it preference over previously developed anesthesia gases (Cote et al., 2019). As healthcare costs have risen, the expense of using sevoflurane has increasingly come under scrutiny. Its use also contributes to the production of greenhouse gases and contributes to unnecessary workplace exposure (Kennedy et al., 2019). Sevoflurane, dosed in percentages, is administered through the flow of other gases. These other gases-oxygen, air, and nitrous oxide flow in liters per minute (LPM) and are referred to as fresh gas flows (FGF). If these flows are higher than necessary, excess sevoflurane is wasted. Many anesthesia techniques show how to decrease sevoflurane use, while providing the same safe, effective 
anesthetics (Kennedy et al., 2019; Lethbridge et al., 2007; Ryu et al., 2011; P. Singh et al., 2014).

Although well documented, strategies to decrease sevoflurane waste sometimes fail to reach clinical practice or are maintained after their initial impact.

\section{Available Knowledge}

Sevoflurane is frequently used in pediatric patients prior to intravenous (IV) access. Liquid sevoflurane is vaporized through a mask and induces unconsciousness, allowing placement of an intravenous line while the child is unaware. The sevoflurane may be delivered at up to $8 \%$ via FGF in LPM (Cote et al., 2019). This technique avoids any needle sticks while the child is awake. Once IV access is obtained, the surgery can ensue with analgesia or other anesthetic adjuncts to be delivered via the IV. The sevoflurane, titrated for effect, maintains the anesthetic depth required after the initial induction, typically around $2 \%$ (Cote et al., 2019).

While inducing a pediatric patient with sevoflurane, fresh gases -oxygen, air, or nitrous oxide may flow $\geq 12$ LPM or more with $8 \%$ sevoflurane. This process of induction, IV-line placement, and then securing of the airway can take some time, particularly if the child has difficult IV or airway access (Cote et al, 2019). It is during induction and the maintenance phase of anesthesia that FGF can be turned down, delivering the same concentration of sevoflurane while reducing the volume used (Tyagi et al., 2014; Gupta \& Datta, 2020). For example, inducing a patient with 8\% sevoflurane at FGF of 12 L then 4 LPM for maintenance versus inducing with $6 \mathrm{~L}$ and maintaining with $1 \mathrm{LPM}$. Using lower FGF during induction and maintenance anesthesia phases utilizes less sevoflurane and is the more cost-conscious choice (Kennedy et al.; 2019; P. Singh et al., 2014).

\section{Literature Review \& Synthesis}

Three databases PubMed, CINAHL, and Cochrane, were searched for relevant studies aimed at determining decreasing sevoflurane usage through modification of use. Seven relevant articles were found using the key words: "sevoflurane," "cost", and "induction". Articles were in English and 
published within the last ten years, except one. This article specifically addressed sevoflurane usage in a children's hospital after an educational intervention intended to decrease sevoflurane usage (Lethbridge et al., 2007). Literature review is summarized in Table 1.

Four randomized controlled trials (RCTs) compared various sevoflurane administration techniques to determine which methods reduced sevoflurane use and associated costs (Gupta \& Datta, 2020; A. Singh et al., 2019; P. Singh et al., 2014; Tyagi et al., 2014). Three other articles looked at sevoflurane consumption before and after an intervention. Two of those were educational interventions encouraging conscientious use of sevoflurane (Kennedy et al., 2019; Lethbridge et al., 2007). The other study compared sevoflurane usage before and after a policy change (Ryu, et al., 2011). The studies using an intervention to decrease sevoflurane usage assessed the use over different time frames. Lethbridge et al. (2007) collected data on sevoflurane usage over a two week period prior to intervetion, then calculated the sevoflurane usage for the two week period post intervention. Ryu et al. (2011) calculated sevoflurane usage for five weeks prior to and fifteen weeks after their intervention. Kennedy et al. (2019) evaluated sevoflurane usage for three months prior to intervention, then calculated the usage in the 6 months post intervention.

Evaluation of sevoflurane adminstration using higher versus lower FGF's can occur when comparing different techniques (Ryu et al., 2011) or by comparing the before and after effects of an intervention aimed at decreasing sevoflurane usage (Tyagi et al., 2014). First, Ryu et al. (2011) investigated the effect of implementing a policy reducing maintenance flows to 1 LPM with anesthesia machines defaulting to 6 LPM when turned on for induction. Staff were informed of the changes and provided reinforcement throughout the study. Tyagi et al. (2014) compared three methods of anesthesia: propofol induction, sevoflurane $8 \%$ with 6 LPM FGF until desired dose reached in the patient, then 1 LPM for the rest of the case, propofol induction with sevo as in first method but with 0.5 LPM FGF for anesthesia maintenance, and sevoflurane induction at 6 LPM then 0.5 LPM of FGF for 
maintenance of anesthesia. Their studies confirmed existing data that shows administering sevoflurane using lower FGF for anesthesia maintenance is more cost effective. They did not, however, look specifically at induction and its influence on sevoflurane consumption (Ryu et al., 2011; Tyagi et al., 2014).

Three studies considered sevoflurane usage during induction and found using lower flows for sevoflurane induction in children resulted in decreased sevoflurane consumption while providing equivalent safe and efficient induction conditions (Gupta \& Datta, 2020; A. Singh, et al., 2019; P. Singh, et al., 2014). Lethbridge et al., (2007) looked at the effect of an intervention on decreasing overall sevoflurane use in a pediatric hopsital where many of the cases were performed using a sevoflurane inhalational induction. They evaluated the impact of lower FGF during inhalational inductions and maintenance of anesthesia on overall sevoflurane use. Reductions in sevoflurane consumption were found resulting in significant cost savings. Similarly, Kennedy et al., (2019) reviewed cases using sevoflurane for induction and maintenance. The data reinforced that FGF rates correlate with sevoflurane consumption and that modifying rates at induction significantly reduces average FGF rates.

A variety of methods were used to quantitate sevoflurane usage. These included weighing sevoflurane vaporizers (Tyagi et al., 2014), using anesthesia machine calculations (Gupta \& Datta, 2020), formulaic calculations (Singh et al., 2014), and averaging FGF rates during a case (Kennedy et al., 2019) . The evaluation of FGF rates for averaging and comparison for study is a pragmatic approach to evaulate sevoflurane usage. Additionally, using electronic data extraction, multiple data sets can be obtained for analysis while maintaining de-identification of individual patients.

All of these studies revealed a decrease in sevoflurane use whether they were looking at comparing techniques or looking at the impact of an intervention. The studies showing an anesthesia technique that lowered sevoflurane usage, focused on decreasing FGF rates. The decrease in FGF rates was during induction or during induction and the anesthesia maintenance phase. Tyagi et al. (2014) 
compared sevoflurane-only anesthetics using two different FGF rates and a sevoflurane plus propofol anesthetic. They found the lower flow, sevoflurane-only technique to be the most cost effective. Comparing different anesthesia induction techniques, P. Singh et al. (2014) found the lower-flow technique used less sevoflurane and was more cost effective.

Three of the four studies comparing anesthesia techniques to reduce sevoflurane usage focused on pediatric surgical patients (Gupta \& Datta, 2020; A. Singh et al., 2019; P. Singh etal., 2014). Pediatric patients are frequently anesthetized using inhalation techniques with higher FGF to get the patient to sleep quickly. This provides an opportunity to focus on reducing usage, because sevoflurane is used for both induction and maintenance of anesthesia. In adults or children with an IV line, induction of anesthesia doesn't involve inhalation of sevoflurane, as IV medications are used to induce unconsciousness (Cote et al., 2019). Of the intervention studies, one (Lethbridge et al., 2007) provides data from a children's hospital where they looked at the FGF rates before and after educational reminders to staff. Two other groups studied sevoflurane consumption in four operating rooms over an eleven month period (Kennedy et al., 2019) or total departmental use of sevoflurane over a twenty week period (Ryu et al., 2011).

Lowered sevoflurane usage and cost savings were demonstrated by each study that provided either an educational intervention or reminder (Kennedy et al., 2019; Lethbridge et al., 2007) or a policy change (Ryu et al., 2011) resulting in a modifcation of technique. The majority of studies comparing techniques focus on pediatric cases, again, revealing the induction phase as a point of potential cost savings (Gupta \& Datta, 2020; A. Singh et al, 2019; P. Singh et al., 2014). Attainment of the cost savings was possible using an intervention with staff such as an educational reminder (Kennedy et al., 2019; Lethbridge et al., 2007) or a policy change (Ryu et al., 2011).

Lethbridge et al. (2007) only studied the effect of their intervention for two weeks, not verifying the lasting impact of the intervention. In 2014, P. Singh et al. compared a high dose sevoflurane 
induction to an incremental one. A high dose technique is frequently reserved for an uncooperative or unmedicated child and may not be considered equivalent to an incremental dosing method. In the studies examining sevoflurane consumption, a theme 'the need for reinforcement to maintain practice changes' emerged (Gupta \& Datta, 2020; Kennedy et al., 2019; Lethbridge et al., 2007; Ryu et al., 2011; A. Singh et al., 2019; P. Singh et al., 2014; Tyagi et al., 2014). Studies also varied in their length of follow up. Kennedy et al. (2019) discussed the 'rebound' of FGF rates six months after the intervention and suggested regular feedback may be needed to maintain the changes. Without reinforcement, Lethbridge et al. (2007) noted that routines of using FGF higher than needed tended to return to near baseline at five months after their intervention. Ryu et al. (2011) implemented a policy change to force use of low FGF, but less than $50 \%$ of staff adopted the change. Sustainment was found to diminish over the 15 week evaluation period.

Unless stakeholders are educated and engaged, adoption of EBP is unlikely. Additionally, practice change reinforcement is essential. Regardless of what method is employed to decrease sevoflurane use, validating sustainability is crucial in order to bring about lasting EBP change.

\section{Rationale}

Evidence exists showing that sevoflurane waste can be reduced if anesthesia staff are educated about using lower FGF to deliver the sevoflurane. Unfortunately, evidence does not always translate into practice. There are several reasons anesthesia providers don't always adjust FGF rates that might reduce the waste of sevoflurane. Inexperience may make a provider forget to turn flows down after the induction phase, or complacency may make a provider less likely to take financial concerns into consideration (Lethbridge et al., 2007). Other reasons clinicians may fail to integrate known evidence into practice include large amounts of research with conflicting results, lack of knowledge or negative attitudes towards EBP, and lack of organizational support for clinicians wishing to implement EBP (Warren et al, 2016). 
Since many pediatric patients are given anesthesia via mask induction, and anesthesia is maintained with sevoflurane, opportunity exists to assess, and decrease the use of sevoflurane. An educational intervention for anesthesia providers which produces a minor practice change, could result in more efficient use of sevoflurane. The reduction in sevoflurane use could then translate to a decrease in cost. Providing a pharmacoeconomically responsible anesthetic is supported through evidence, but many providers induce and maintain sevoflurane anesthesia with higher than necessary flow rates (Gupta \& Datta, 2020). Cost savings can be realized, and there are also potential benefits for patients. Cote et al. (2019) notes hypothermia in children receiving anesthesia can be a common issue and higher FGF than necessary for a longer time than necessary can contribute to hypothermia in smaller patients as room temperature air is flowing around the patient's core. Fresh gases are completely dehumidified and can contribute to airway irritation during a time when patients are prone to laryngospasm and bronchospasm, particularly if they are flowing at rates which are higher than needed (Cote et al., 2019). Additionally, high FGF also increase anesthesia provider's sevoflurane exposure when there is any compromise in a mask seal or disconnect of the breathing circuit. Finally, sevoflurane, like many other volatile anesthetics, is a strong contributor to greenhouse gases. MacNiell (2017) noted that in the provision of healthcare services at three major hospitals, anesthesia gases were found to be the largest contributor to greenhouse gas emissions.

\section{PICO Question}

In same day pediatric surgical patients receiving mask inductions, will the implementation of an EBP educational program on sevoflurane usage for anesthesia providers, compared to usual routine, decrease the amount of sevoflurane utilized after the program at one and three months?

\section{Theoretical Framework}

Lewins' Change Theory was applied to this project. As described by Petiprin (2016), Lewins' Change Theory purports behaviors change when there is an imbalance of reasons driving a person to 
change a behavior. If forces of change are equivalent to forces that prevent change, an equilibrium is present. If forces that drive change are increased, then a change in behavior can occur. In this case, the educational intervention about sevoflurane would provide information to motivate anesthesia providers to change their practice.

Lewins' Change Theory has three phases: unfreezing, change, and refreezing (Petiprin, 2016). The unfreezing would occur with the presentation of the educational intervention on decreasing sevoflurane use. The change would occur when the novel information is transformed into the modest adjustment of using lower flows during sevoflurane administration. Finally, refreezing would occur when the use of lower sevoflurane flows becomes integrated into practice.

\section{Project Aims}

The aims of this project were to implement an educational program of EBP sevoflurane administration and to evaluate the program impact on sevoflurane use. Additionally, provider attitudes and knowledge regarding sevoflurane administration were assessed. (See Table 2).

\section{Methods}

\section{Needs Assessment}

While evidence shows that wasting of anesthesia gases occurs (Lethbridge et al., 2017) and can contribute significantly to the production of greenhouse gases (MacNiell et al., 2017), that evidence has not translated into practice at a large university hospital where the author is employed. According to the operating room pharmacy records, the institution where the project took place has annual expenditures of approximately $\$ 300,000$ annually on sevoflurane (E. Likar, personal communication, July 2020). This project evaluated the impact of an educational intervention with anesthesia staff to produce a decrease in sevoflurane consumption and associated costs. The setting is affiliated with a Research 1 Doctoral Extensive Carnegie rated university in the US mid-Atlantic region.

\section{Intervention, Context, \& Population}


This project involved the collection of deidentified data from the electronic health records (EHR) of three groups of 100 cases ( $N=300$ cases total) of pediatric patients undergoing anesthesia for sameday surgery. One group was before and two groups after the educational intervention concerning evidence-based sevoflurane use for anesthesia providers. Data set one, or baseline was obtained from a month prior to delivery of the educational intervention and before the start of gathering buy-in from anesthesia department members. The first post education data set was collected the month immediately after the educational offering and then again at three months to validate sustainment of the EBP change. The data collected is the average FGF during an anesthesia case from the time of anesthesia start to the completion of the surgical procedure. It included pediatric same-day surgery cases using sevoflurane for mask, also referred to as inhalational induction, and maintenance of anesthesia. Each month of collection of average FGFs used was determined for 100 cases until a total of 300 cases was reached. The number needed to evaluate was established using Joint Commission guidelines for quality improvement (QI) projects, input from committee member statistics expert, and based off numbers utilized in previous interventions.

The intervention was an educational presentation on EBP change, to all anesthesia faculty, staff, and students, provided as part of a routine anesthesia department grand rounds. The presentation occurred in a large auditorium with available technology for the presentation of a power point with accompanying lecture. Adjustments in the delivery of the presentation due to the pandemic required its presentation virtually via a Zoom link for anesthesia grand rounds for recipients who chose not to attend a large gathering. A retrospective or pre- post-survey was provided for participants to take after the presentation via a link to Qualtrics and the data analyzed to determine the immediate impact of the educational session. The survey compared before and after knowledge regarding sevoflurane and changes in FGF, as well as attitude toward EBP practice change regarding both economic and environmental concerns. It was expected that the presentation would be adopted as part of ongoing 
departmental educational needs. Avorn, (2017) discussed the development of academic detailing - a concept similar to pharmacy representatives who would come to clinic periodically to provide inservices about new medications on the market and noted two visits in six months was frequent enough to make an impact on provider's clinical practice and decision making. Academic detailing is like the educational strategies used to alter pharmaceutical prescribing practices, including short, intense, one on one sessions with a content expert or opinion leader (Avorn, 2017). Providing bi-annual education about EBP sevoflurane use combined with academic detailing during clinical work provided a foundation for the change (Avorn, 2017). It was provided bi-annually to reinforce the expected practice change and would then be adopted for onboarding of new anesthesia providers and learners. The presentation along with academic detailing would reinforce and sustain the EBP practice change. Biannually cost data would be evaluated with pharmacy and incorporated as part of departmental meetings to reinforce the economic benefits of the change.

The mission of the healthcare corporation is "to improve the health of the citizens of the surrounding area served by the hospital through excellence in patient care, research, and education" (West Virginia University; WVU Medicine, 2020). The project aims encompass delivering safe, costeffective care, while completing EBP implementation and evaluation, which aligns well with the institution's mission.

By nature, the delivery of anesthesia involves delivery of a variety of pharmaceutical agents, sevoflurane being among them. Pharmacy departments frequently have initiatives to decrease drug costs associated with anesthesia delivery. These initiatives are typically associated with intravenous drugs that go unutilized, requiring their waste. These unused or unattended medications are visible to staff working in the operating room, reported to pharmacy, noticed by administrators, and even noted in inspections by accrediting bodies such as Joint Commission on Accreditation of Healthcare Organizations. Consequently, there is increased interest in pharmacoeconomic accountability and 
sustainability within many anesthesia departments. According to the operating room pharmacist at the project hospital, annual expenditures for sevoflurane are over $\$ 300,000$. An initiative to decrease these costs is in line with the efforts of both the anesthesia and pharmacy departments.

In addition to cost benefits, decreasing sevoflurane use has potential benefits for the environment. MacNeill et al. (2017) studied three hospital systems and found that operating rooms are significant contributors to environmental pollution. Anesthesia personnel delivering sevoflurane to patients also face some exposure to sevoflurane during mask induction of anesthesia and during any disconnects of the breathing circuit during a case. Evaluating greenhouse gas emissions from anesthetic agents, Sherman et al. (2012) recommended all volatile agents be delivered with the lowest FGF possible to reduce their impact on the environment. Lowering the amount of FGF, such as oxygen and air combinations, which carry the sevoflurane, would lessen these exposures and the potential environmental impacts.

\section{SWOT Analysis}

A SWOT analysis determines the strengths, weaknesses, opportunities, and threats to a clinical project (Bonnel \& Smith, 2018). Strengths identified for this project include rapport with current anesthesia department members, buy-in from pharmacy, and anesthesiology leadership. Additionally, there were no expected interruptions to workflow with project implementation. The author was the clinical coordinator of anesthesia as well as a pediatric cardiac anesthesia team member at the institution of interest, and able to carry out this project as part of QI duties. Cost absorption occurred as the project was conducted in the author's clinical role as anesthesia department "release time". The economic environment was ideal for a cost savings initiative. An established connection existed with IT department's anesthesia specialists. Finally, there is a general cultural interest in environmental impact and carbon footprint of industries including healthcare. To avoid a conflict of interest, faculty from 
outside of anesthesia were part of the team to ensure objectivity and congruence with the academic mission of the organization.

Weaknesses included the inability to reach all staff with the educational intervention or complacency of staff in making changes. As an academic center, an increased number of learners could have also been a weakness (Kennedy et al., 2019). When developing and advancing airway management skills, learners often use increased flows to compensate for a poor mask seal. If the mask isn't snuggly fitted to the patient's face, gases can leak out increasing FGF to compensates for the leak. Turnover of staff or new learners could have also impacted project success as they may not have received or be aware of the information provided in the educational intervention. Adding the educational intervention to the onboarding process helped to minimize the potential for missed opportunity to educate staff on efforts to reduce production of excess waste anesthesia gases.

Opportunities included development of team cohesiveness for a future pediatric anesthesia team, increased pharmacoeconomic accountability and cost savings, development of interprofessional relationships through collaboration on the project, and lessening the production of greenhouse gases and staff environmental exposure to sevoflurane. Low motivation in overworked staff, the lack of administrative support, and failure to identify cost savings were potential threats. Therefore, the educational program was incorporated with routine grand rounds (see Appendix A) and documented administrative support was gained upfront (see Appendix C).

Lastly, pharmacoeconomic accountability is increasingly of concern to patients, institutions, and healthcare payors. This project aimed to decrease expenditure on sevoflurane at a university hospital. According to their pharmacy director, expenditures are over $\$ 300,000$ annually on sevoflurane (E. Likar, personal communication, July 2020). By decreasing the amount of sevoflurane delivered to patients undergoing surgery at this hospital, significant cost savings could be realized. 
Attainment of project aims was through educating staff in a routine meeting on the delivery of sevoflurane. An EBP educational session was developed by the author (see Appendix A). Approval from both the university, which deemed the project as non-human subject research (NHSR), and hospital institutional review boards (IRBs) was obtained in late 2020 (see Appendix D). The EBP intervention was utilized as a review or update for anesthesia providers' knowledge base, allowing them to integrate evidence into their practice that decreases usage of sevoflurane and lowers costs. The educational intervention was presented during a routine meeting by the investigator. Staff not available to attend were briefed and surveyed individually as part of the normal workflow routine by the author. Staff not attending grand rounds the day of the educational intervention were emailed a recorded copy of the presentation with a link and QR code for the post-education survey. Academic detailing ensued during clinical activity. On a regular and recurring basis, the investigator checked in with anesthesia staff concerning the project to assess for any questions or concerns and reinforce the project aims. Two weeks after the session, a supportive article was provided via the anesthesiology department's intranet website with a bi-monthly educational article, which went out to anesthesia staff. The author used the article as a form of academic detailing to enhance staff understanding, reinforce knowledge, and willingness to reduce sevoflurane use.

Specifically, this project focused on pediatric, same-day surgery cases at a university hospital. The data collected was from cases in which pediatric patients received sevoflurane for induction and maintenance of anesthesia. Because high gas flows deliver high concentrations of sevoflurane, these types of cases were particularly suited to reducing sevoflurane use. The educational session, however, was delivered to all anesthesia providers, leaving opportunity for future evaluation of overall institutional impact and departmental pharmacoeconomic accountability as well as sustainability.

Changes in sevoflurane use were tracked by collecting average FGF rate per case for a total of 300 cases. Included cases were cases in which sevoflurane was used for induction and maintenance of 
anesthesia. Sevoflurane use can be directly correlated with average FGF rates (Kennedy et al., 2019). The investigator tracked the number of cases to be included in the practice change using an electronic code list, which was kept on a HIPAA compliant computer, and locked in the investigator's office. Average FGF (in LPM) was monitored on 300 total cases. 100 cases in a one-month period before the educational session, and 100 cases at one month and three months after the educational intervention. The average FGF rates for the cases was obtained through the electronic health record anonymously in an excel spreadsheet to track the sevoflurane use over time for comparison and was correlated with the demographic case data. Once the data was obtained regarding sevoflurane use, the electronic case code list was destroyed by the investigator using HIPAA compliant electronic methods at the institution. Reduction of sevoflurane use through similar interventions revealed decreases in sevoflurane use from 26-53\% (Lethbridge et al., 2007; Tyagi et al., 2014). As such, a goal was set at a $20 \%$ reduction in sevoflurane use in study cases after the educational session.

There are gaps in the integration of evidence into practice when it comes to using sevoflurane. Although multiple authors have shown decreases in sevoflurane use with attention paid to technique or methods using lower flows, it is not an established standard (Kennedy et al., 2019; Lethbridge et al., 2007). Additional issues in the project may have included bias with the questionnaire for staff, as the questionnaire was a pre/post questionnaire given one time after the educational presentation. Anesthesia providers took the post education survey voluntarily, and bias could be present if those who chose to respond were more motivated to integrate the information into practice or to show a positive response to the educational information. This type of survey was selected due to it was deemed more compatible and acceptable with time constraints of providers. Additionally, given the ongoing pandemic, concern for "mission fatigue" could also have influenced the project. At the projected time of implementation of this project, staff were a year into a pandemic which significantly altered their professional schedules and duties as well as their ability to travel and socialize. Staff feelings of burnout 
and frustration could have possibly disincentivized them to participate or to participate fully in the efforts of this project.

Potential weaknesses may exist in the project design. One of these may be looking at only the pediatric same-day surgery cases, as they may not be representative of equivalently attainable costsavings in other patient populations. Another may be utilizing average FGF rates for estimating sevoflurane use. Other less feasible and more technically difficult methods exist. For example, weighing sevoflurane vaporizers before and after each case or using formulaic calculations (Gupta \& Datta, 2020; Tyagi et al., 2014). These methods may be considered more accurate but are not always utilized because they can disrupt workflows and be logistically difficult. The impact of the educational intervention could reach other patient populations, and this data was not captured as part of the project. However, the study took place at an institution where a new children's hospital is set to open. There are growing numbers of pediatric cases occurring which increases the potential impact of focusing on pediatric patients.

The implementation of this project occurred as part of a QI effort in the anesthesia department under leadership of the investigator. A timeline was created for the project and then adjusted over time as delays occurred in proposal editing, approval, and in obtaining an available date and time for presentation at anesthesia grand rounds (see Figures 1 and 2). The project was approved by anesthesiology leadership from department chairs of anesthesiology and pediatric anesthesiology and the residency coordinator (see Appendix C). The investigator had dedicated time as part of administrative duties associated of the position, requiring no supplemental salaried staff. Additionally, project work occurred during off-work (unpaid) hours with approval of the department chief. Delivery of the educational intervention for anesthesia staff occurred as part of a routine meeting, requiring no additional staff hours. Gathering of electronic data to quantitate sevoflurane use was through coordination with IT and pharmacy colleagues demonstrating the investigator's team leadership and 
collaboration skills. Incidental costs of printing or other nominal incidentals incurred were absorbed by the investigator. Project hours were tracked in order to determine investigator time to implement the practice change.

This QI project aimed to increase pharmacoeconomic accountability in the anesthesia department at a large university hospital in WV by decreasing the amount of sevoflurane wasted.

\section{Outcomes}

Evaluation of outcomes is an important part of any QI project. Evaluation of outcomes can demonstrate accountability and success or failure of a project (Bonnel \& Smith, 2018). Basic demographic included type of provider (CRNA, MD, SRNA) and length of practice of the anesthesia providers. This data was collected and reported in aggregate using descriptive statistics. One outcome measured included the impact of the educational intervention on anesthesia providers' knowledge of sevoflurane use and attitudes toward making a minor practice change to decrease use. The other outcome measured was the use of sevoflurane estimated through anonymous collection of average FGF rates in pediatric inhalational mask induction cases using sevoflurane (see Appendix E, Evaluation Plan).

\section{Analysis}

The impact of the educational intervention was measured in a brief survey provided after the educational session was given. The post survey data was compared with pre-session responses. The questionnaire was a retrospective or pre- then post-survey given once after the session. This type of survey offers strength to the evaluation of impact of the educational intervention by comparing participants' knowledge and attitudes before and after the education in a single survey (Taylor-Powell \& Renner, 2009). The questions included inquiry of participants knowledge of sevoflurane use, its impact on the environment, concerns regarding use of low FGF to deliver sevoflurane, the potential to decrease sevoflurane use by using lower FGF rates, decrease in costs associated with lower FGF, and willingness to integrate this knowledge into a minor practice change. The educational intervention was planned and 
delivered in the Spring of 2021. Scores obtained for before-and-after answers on the survey were compared using a paired t-test. The survey (see Appendix A) was loaded into Qualtrics for ease of completion and data collection and analysis. It was then piloted in September 2020 with three anesthesia providers to assess face value and ease of use. The pilot use confirmed congruence with intent.

Further evaluation of the impact of the educational intervention was generated by tracking sevoflurane use on a total of 300 designated pediatric cases, 100 cases at baseline and one and three months each post educational program. If the providers understood and integrated the information from the educational intervention into their practice, then they would be using lower average FGF rates to deliver the same dose of sevoflurane. The use of sevoflurane can be measured by monitoring FGF rates (Kennedy et al., 2019). Fresh gases consisting of air, oxygen, and nitrous oxide are used to deliver sevoflurane in concentrations up to $8 \%$. It is delivered through a mask in many pediatric cases where an IV line is not placed until the patient is unconscious from the inhalation of anesthesia gases. The fresh gases are turned on in combinations chosen by the anesthesia provider to deliver sevoflurane to a patient. Sevoflurane usage has a linear relationship to FGF rates (Kennedy et al., 2019). The sevoflurane usage was estimated by tabulating average FGF rates in LPM used during these pediatric cases. The fresh gas flow rate is recorded in the electronic health record and was obtained anonymously for data analysis. The FGF rate was averaged from the time the sevoflurane is turned on until the "procedure finish" event when sevoflurane is turned off. A total of 300 cases had FGF data averaged. Data was obtained from the EHR using an excel spread sheet developed by the author (see Appendix B). Some initial manual calculation was required to add minutes of nitrous oxide use into the calculated average fresh gas flow rate as the EHR reports pulled for each case would not add in any minutes of nitrous oxide use when calculating average fresh gas flows. The three different sets of average FGF data were compared using an analysis of variance or ANOVA test. Assistance in statistical analysis was established 
from a statistics expert of the associated university, as part of the project committee. Analysis of the three data sets determined if there was a significant reduction in average FGF rates. Data extraction and analysis occurred in the spring of 2021 through the early fall of 2021 until 100 cases of data were obtained for each data set time point (baseline, month 1, and month 3).

\section{Ethical Considerations}

Approval from both the university IRB and hospital nursing research council was obtained (see Appendix D). Data was obtained from EHRs in collaboration with the anesthesia IT department and pulled through reports created by IT and run by the investigator. All information was deidentified and stored on a password protected computer or encrypted flash drive. No human subjects were manipulated in this project. Delivery of the educational presentation to staff was part of the routine departmental educational processes and did not involve coercion or manipulation of staff. The pre/postpresentation survey was anonymous and voluntary in nature. Taking of the survey was neither incentivized nor punitive in nature. Additionally, a project team member that was not part of the anesthesia department (Faculty of Record) helped in maintaining project objectivity and addressing any potential conflicts of interest from the author or subject matter expert, who are both members of the anesthesia department used to demonstrate this QI project to staff or learners. Employing an EBP educational presentation to induce a lasting practice change was one of the aims of this project and is congruent with the mission and vision of the institution.

\section{Results}

\section{Aim 1}

Aim 1 for this project was implementation of an EBP educational program to decrease sevoflurane use. This was carried out in Spring 2021 through objectives of delivering the lecture discussion at an anesthesia grand rounds. No problems were encountered in the delivery of the education or with the academic detailing that ensued. After delivery of the educational presentation on 
sevoflurane administration, the pre-post survey on knowledge and attitudes towards sevoflurane use was offered via a link was delivered to all attendees for completion (objective 1b). Anesthesia staff who were not present were provided the educational presentation in person or via email with recorded audio. Participants completed the survey via link or QR code taking them to the Qualtrics survey. Participants who were not present at the initial presentation were delivered the educational material over the next three working days excluding some per diem staff or staff members on vacation.

Comprehensive academic detailing ensued with anesthesia providers throughout the department during individual breaks in operating rooms or during staff break times in the anesthesia break room in the months following the educational presentation on a minimum of a weekly basis. Staff numbers included a total of sixty-seven full or part time CRNA's, thirty-five attending anesthesiologists, and twenty-four residents were offered the education and survey $(n=126)$. On a given day there are varying numbers of student nurse anesthetists from different programs, typically between two and four. Of those, seventythree anesthesia providers took the Qualtrics survey with sixty-six (52\%) participants completing the survey.

Survey respondents were largely Certified Registered Nurse Anesthetists (65.3\%), followed by anesthesiology residents (13.9\%), anesthesiologists (12.5\%), and student nurse anesthetists (8.3\%). Nearly half of respondents (45.8\%) had $0-5$ years of experience. Only $22.2 \%$ of those respondents were either anesthesiology residents or student nurse anesthetists. The remainder were CRNA's or residents in their first few years of practice. Of respondents, $13.9 \%$ had six to ten years of experience. About onefifth (22.2\%) had greater than fifteen years of experience and $18.1 \%$ had eleven to fifteen years of experience. As expected, student nurse anesthetists and residents tended to have less years of experience. Summary of provider demographic data are detailed in Table 3, Survey Demographic Data: Provider Type \& Years of Practice. 
Survey questions regarding knowledge and attitudes towards sevoflurane use, FGF rates, costs, and environmental pollution were recorded through Qualtrics (https://www.qualtrics.com). The data was then input into SPSS software for statistical analysis. Using a Likert scale for before and after ratings of presentation, " 1 " indicated "none" and " 5 " indicated "a lot." A paired t-test was used to compare before and after scores to each question. Through survey answers, respondents noted a statistically significant change in knowledge regarding sevoflurane waste contributing to environmental pollution and increasing costs. In addition, respondents' attitudes regarding willingness to integrate evidence into practice, change their practice to reduce sevoflurane waste to reduce environmental pollution, and change practice to reduce costs also increased significantly $(p<0.001)$ for all questions regarding knowledge and attitudes. Statistical analysis including means, standard deviation and significance are detailed in Table 4. In response to "my knowledge of sevoflurane's contribution to environmental pollution," respondents mean score before was 2.74 , and after was 4.48 . In response to "my knowledge of how much fresh gas flows impact sevoflurane waste" respondents mean score before was 2.12 and after was 4.52. In response to "my willingness to integrate evidence into practice," respondents mean scores before and after were 3.60 and 4.67 respectively. In response to "my willingness to change my practice to reduce sevoflurane waste and environmental pollution," respondents' means scores were 3.31 before and 4.69 after. In response to "my willingness to change my practice when using sevoflurane to reduce healthcare costs," respondents' mean score before was 3.35 and 4.56 after receiving education. Both before and after responses for each knowledge or attitude question from the survey are detailed in Figures 3-7.

\section{Aim 2}

Aim 2 was to evaluate the impact of an educational Program on EBP sevoflurane use on sevoflurane usage. Deidentified baseline data from 100 cases meeting inclusion criteria was collected at three different time intervals $(\mathrm{N}=300)$ for evaluation of average fresh gas flows, time to airway, and 
procedure length for baseline (data set 1 ), month 1 (data set 2 ), and month 3 (data set 3 ). The collection of these data sets addressed objectives $2 a, 2 b$, and $2 c$ (see Appendix E). Case inclusion criteria were pediatric, same-day-surgery cases, using sevoflurane for induction and maintenance of anesthesia, and with a procedure length of less than 180 minutes. Due to impacts on case load at the hospital from the COVID-19 pandemic, baseline data the month prior to the delivery of the educational material was lower than usual and baseline data was retrieved from the fall prior to the pandemic. Obtaining data from this period excluded holiday fluctuations as well as impacts of the pandemic on case numbers as well as any early influences of discussion of project development influencing providers in the department to begin making practice changes. One month after the educational presentation was delivered to staff, data for another 100 cases was collected. This process was repeated at three months after the educational presentation. Once data collection was underway for month three, it was noted that data for same-day-surgery pediatric cases was being collected from only the main operating room where both same-day-surgeries and inpatients or post-operative admission cases occur and not the same-day surgery suite located on a separate floor of the institution. This resulted in a disproportionate representation of residents in the data as compared to the actual ratio of residents and Certified Registered Nurse Anesthetists at the institution. Upon review with committee members, it was decided to proceed with the data obtained, as the aim of the project was to determine if, as a department an impact can be made on waste of sevoflurane and not to compare the results of based upon provider type. All months of data collection required going into the first week of the following month to obtain the final cases to reach 100 for each data set. Cases were excluded if they did not meet the criteria previously listed. Others were excluded if data was missing from the record due to the electronic record not being started in a timely fashion or data interface down times or glitches created gaps in data collection in the EHR's anesthesia record making accurate recording of average FGF impossible. 
Parametric testing was used to compare the means between groups: baseline, month 1, and month 3. Specifically, ANOVA was conducted on the three data sets to determine if the difference between means was significant between groups in comparison of procedure length in minutes, time to airway in minutes, and average fresh gas flow in liters per minute (L/min). See Table 5 for the ANOVA summary. Average procedure length was the total number of minutes it took to complete the procedure noted in the EHR from the event "incision" until the event "procedure stop." Overall average procedure length $(M=59, N=300)$ minutes. See Figure 10 for a graphic representation of procedure length. The ANOVA of procedure length showed procedure length was not statistically significant between groups, $(F=.878, p=.417)$. Mean procedure lengths were in minutes 56 (data set $1=$ baseline), 58 (data set $2=$ month 1), and 63 (data set 3=month 3) respectively. See Table 2 for descriptive statistics of procedure length, time to airway, and average FGF.

The overall mean number of minutes to secure the airway was 7.4 minutes ( $N=300)$. The ANOVA of minutes to airway showed means were not statistically different, $(F=1.836, p=.161)$. Minutes to secure airway were noted from the minute the event "induction" was noted in the EHR until the event "intubation" or "LMA placement" was noted. In the case of a mask only case where the airway was not secured with a device, event of "anesthesia release" was noted for airway securement. Mean minutes to secure airway also did not differ significantly between data sets and were 8.1, 7.3, and 6.9 minutes respectively for each data set (baseline, 1 month and 3 months). See Figure 8 for a graphic of time to airway for each data set and Table 5 for the ANOVA summary.

Overall mean FGF was $3.88 \mathrm{~L} / \mathrm{min},(M=3.88, N=300)$. Mean FGF decreased from baseline to month one, and from month 1 to month 3 (see Figure 9). Fresh gas flows were averaged from the start of sevoflurane on the anesthesia record until event "procedure finish" when anesthetic gas administration ceased. A one-way ANOVA was conducted to evaluate the relationship between delivery of an educational intervention on EBP sevoflurane use and FGF before the education and after at 1 and 
3 months. The independent variable included impact of education, baseline (before) and after ( 1 and 3 months). The dependent variable was average FGF. The ANOVA of average FGF was significant between groups: baseline, month 1 , and month $3,(F=4.387, p=.013)$.

Post Hoc analysis using Tukey's testing revealed statistical significance between FGF baseline and month 3, but no statistical difference in procedure length or minutes to airway. Average FGF between data set 1 (baseline=4.19 L/min) and date set 2 (month $1=3.94 \mathrm{~L} / \mathrm{min}$ ) decreased but did not differ significantly. Average FGF from data set 2 (month 1=3.94 L/min) and data set 3 (month 3=3.53 L/min) again decreased but did not differ significantly. However, average FGF from data set 1 (baseline $=4.16 \mathrm{~L} / \mathrm{min}$ ) and data set 3 (month $3=3.53 \mathrm{~L} / \mathrm{min}$ ) showed a statistically significant decrease with $(p=.011)$. For Tukey's test summary see Table 6 .

\section{Discussion}

\section{Summary}

Providing an educational intervention to anesthesia providers at this large university hospital resulted in a significant increase in providers' knowledge and attitudes toward sustainable use of sevoflurane. Education was provided at an anesthesia weekly grand rounds meeting targeting the largest number of providers in the department at once with a live presentation. Academic detailing allowed providers who weren't present to receive the educational information either in-person or via email. Academic detailing, when educated and trained professionals familiar with the EBP information take part in concerted efforts to educate staff for purposes of eliciting practice changes based on current evidence was essential (Avorn, 2017). The efforts to reduce average FGF were reinforced through extensive academic detailing consisting of regular and repeated personal interactions with multiple staff as the project leader actively moved through and had contact with multiple staff members in a given workday. A journal article was disseminated supporting the efforts to reduce waste of sevoflurane and encourage use of lower FGF for both induction and maintenance of anesthesia. In 
addition, institutional support gained momentum throughout the project as the pharmacy department enlisted the project to go system-wide and include recommending lower FGF in practice for not just pediatric same-day-surgery cases, but all cases utilizing inhalational agents. In addition, the hospital system adopted a green initiative, Mission Green, during the project to address system wide efforts to reduce the carbon footprint as an institution. Reinforcement of the project efforts was discussed with and supported by departmental leaders such as the director of perioperative services for the upcoming children's hospital, the chiefs of anesthesia residency, and the lead CRNA's. An educational presentation on sustainable use of anesthetic agents was delivered to the department very near the six-month mark from the project's initial effort. The continued academic detailing and education to department staff echoes recommendations from previous researchers who found repeated, reinforcement is likely needed to accomplish a lasting change in practice. (Gupta \& Datta, 2020; Kennedy et al., 2019; Lethbridge et al., 2007; Ryu et al., 2011; A. Singh et al., 2019; P. Singh et al., 2014; Tyagi et al., 2014). The survey taken by respondents showed a favorable shift in knowledge and attitudes towards more conscientious use of sevoflurane. Efforts to reinforce the projects goals were occurring several times per week in personal interactions with staff, residents, and students. Widely shared with department members were the Mission Green efforts of the hospital which were aligned with the efforts of this project, as well as the interest from pharmacy in propagating the project into a system-wide inititative to reduce FGF for any cases in which they are used. Staff were educated on the project's aim to make a practice change that is permanent and not only noticable during a brief data collection period. Staff were encouraged to share their knowledge with any learners and students they worked with while providing anesthesia. Provider feed back during the project was favorable and many reported it was difficult to change their typical habits in practice. Positive reinforcement and encouragement was given to anesthesia providers during academic detailing efforts. 
Between data sets of baseline, month 1 and month 3 post-educational intervention, procedure length did not differ significantly. The maximum procedure length was 180 minutes in attempt to capture all same-day-surgery pediatric cases. Less than half-a-dozen cases were excluded based on procedure length. If procedure length had differed significantly among data sets, additional calculations would have been required. This is because the induction period, typically around five to ten minutes, is a time where FGF are typically significantly higher than during tha maintenance phase of anesthesia. If a group of cases had a lower procedure length, the induction phase would have a greater impact on average FGF for any given case. For example, 7 minutes of FGF at induction will create a higher average FGF in a 20 minute case versus a 60 minute case.

The reductions in average FGF recommended in this project did not result in an increase in time to secure airway and are therefore considered a safe, efficient means of increasing sustainability through reduced costs and decreased environmental pollution (A. Singh et al., 2019). The educational intervention provided to anesthesia staff at this institution recommending using reduced FGF for the delivery of sevoflurane for induction and maintenance of anesthesia mirrored the same efficiency found in earlier interventions and did not result in any increase in minutes taken to secure the airway. In fact, minutes to airway securement actually decreased in each consecutive data set although not at a statistically significant amount. This may be attributable to the recommendation to prime the anesthesia circuit prior to placing it on the patient's face. The education provided to staff highlighted that placing an unprimed circuit and mask on a patient's face for inhalational induction is essentially synonymous to restraining the child by the face with very little sevoflurane in the circuit for the first 30-60 seconds. Waiting for the passage of three time constants, allows for a more rapid induction. The passage of three time constants, typically less than a minute when priming an anesthesia circuit, allows $95 \%$ of that circuit to be filled with the desired dose of sevoflurane for induction. In addition, after priming of a 
circuit, fresh gas flows can be reduced to a patient's minute volume, simultaneously conferring the efficiency of a primed circuit with a sustainably favorable FGF rate.

\section{Interpretation}

Previous studies have noted that decreases in average FGF as a reflection of inhalational agent use, are a producible response to interventions with staff such as policy changes, anesthesia machine soft defaults to 6 L/min FGF, staff education, and reminders to staff (Gupta \& Datta, 2020; Kennedy et al., 2019; Lethbridge et al., 2007; Ryu et al., 2011; A. Singh et al., 2019; P. Singh et al., 2014; Tyagi et al., 2014). The educational intervention at this institution resulted in significant changes in anesthesia providers' attitudes and knowledge towards the sustainable use of sevoflurane. Also, the educational intervention at this institution resulted in a statistically significant decrease over time in average FGF in pediatric same-day-surgery cases. The project goal of reducing average FGF was attained. The goal of reduction of average fresh gas flows was set at a $20 \%$ reduction. The attained reduction in average FGF was $14.9 \%$ which was the noted statistically significant decrease from baseline data set to data set three, collected in the third month after the implementation of the education to the department. Staff responded favorably to education and ongoing project efforts, while serendipitous institutional support arose and most likely helped the project gain ground and afforded additional support.

\section{Limitations}

The delivery of the pre-posttest immediately after the educational intervention creates a threat to internal validity. The questions were answered for both "before" and "after" after receiving the information regarding EBP sevoflurane use. Participant's answers in the survey taken after receiving education about sevoflurane may have been influenced by sensitization. Sensitization can influence respondents' answers particularly when attitudes are being measured (Polit \& Beck, 2017).

Because this project focused on pediatric same-day-surgery cases which used an inhalational induction method for anesthesia versus an intravenous induction method used in adults, results 
produced in this study may not be the same as those seen if cases of adult same-day-surgery cases were studied. This project focused on anesthesia providers at a large university hospital. In such an environment, many anesthesia providers are in training, and this could affect their ability to implement practice change either in favor of making a practice change because they are at a stage of their training where they are developing new skills, or against a change in practice that uses lower FGF. This is because using higher flows assists in mask ventilation technique, like that used during mask inhalational induction of a child and can compensate for an inadequate mask seal. In addition, a learner new to pediatric anesthesia may not prioritize reducing flows over mastering basic airway management skills needed in pediatric anesthesia. It is also possible that providers with many years of experience may find it more difficult than newer learners to make changes in their practice if using higher than necessary FGF has become dogmatic behavior. Retrieval of data from the EHR required some cases to be excluded due to missing data from intranet downtimes or connectivity issues. Whether or not these relatively few cases could have influenced average FGF rates, procedure times, and time to airway remains impossible to determine. Data could only be tallied and analyzed from EHR's which had complete anesthesia records.

This project was carried out through the efforts of a staff CRNA completing a doctoral level program. This was the first incidence in this department of a CRNA undertaking a large educational centered EBP change and coincided with project rollouts from an inaugural class of student registered nurse anesthetists' projects. It was in an environment where multiple anesthesiology residents were also completing projects, and could have failed to gain stronger support because of the novelty of a CRNA attempting a department-wide change and because the project and its efforts may have been lost among multiple other projects occurring at the time. The simultaneous occurrence of the institution's Mission Green and attention from the pharmacy department regarding cost saving measures was 
serendipitous and most likely prevented this project from being yet another in the long cast of student projects being rolled out during this time.

\section{Conclusions}

Delivery of an education intervention to anesthesia providers can impact their practice to produce a positive change. Specifically, recommendation for utilizing lower fresh gas flows by educating staff on the impact of waste anesthesia gas production on costs, the environment, and patients. Based on current expenditures, estimated savings of on sevoflurane annually based on percentage reduction of FGF during this project could exceed $\$ 40,000$. Suggestions of various minor practice changes that could be implemented were delivered at the educational intervention. This information was reinforced through a departmental journal article shared via intranet and through extensive academic detailing by the researcher who was clinically active and available to interact with staff to propagate the information, inform and discuss ongoing efforts.

This project sparked interest in the pharmacy department and generated additional efforts to produce system-wide efforts to reduce waste anesthesia gas production in the interest of pharmacoeconomic accountability and sustainability. Although the project proposal and garnering of institutional support focused on economic benefits, education with staff focused on economic and environmental concerns, as well as benefits to patients. It was believed that the idea of being monitored by efforts of the institution for purposes of reducing costs alone, would be less palatable, and would impact and motivate more anesthesia providers to change if it was not packaged solely as a "cost reduction effort". In addition, during the project's evolution, an initiative was adopted by the hospital to promote sustainability efforts throughout the institution. The interest of the pharmacy department in this project and the adoption of a green initiative at the institution were used in discussions during academic detailing to bolster support for the desired practice change. It encouraged providers to adopt the use of lower FGF not as a temporary measure while data collection was underway, but as a 
permanent practice change that aligned with institutional efforts. The pharmacy department at the institution is currently discussing strategies for monitoring of anesthesia gas usage in the future. In effect, the efforts of the pharmacy, the institution's green initiative and this project worked together to further the project effort.

Volatile anesthetic agents are a predominant part of most anesthetics. In pediatric anesthesia, sevoflurane is commonly used for induction and maintenance of anesthesia. With sevoflurane, a child is anesthetized by an inhalational method, avoiding IV placement and needle sticks in a conscious child. The delivery of sevoflurane has benefits due to its safe, rapid on and offset; however, there are drawbacks. Some of these include unnecessary waste or excess use during delivery. This is because it is administered via the flow of other fresh gases such as oxygen or air. These gases can be turned up in excess of what is needed to deliver an adequate dose. This leads to increases in anesthesia expenses. Other concerns include its contribution to environmental pollution, work exposure to volatile agents, and airway irritation or cooling of patients with high FGF. Studies have identified interventions that compel staff to make changes significantly reducing sevoflurane use (Lethbridge, et al., 2007). Despite this, many of these studies did not have long-term follow up or have shown a rebound to baseline tendencies months after the intervention occurs.

This project was evaluated over time, used academic detailing for reinforcement, and adopted for onboarding of inexperienced providers. After the initial education was delivered and followed with additional efforts to reinforce practice change, a significant decrease in average FGF occurred by month 3 post education. Providers have given feedback acknowledging it took them some length of time to alter their practice to remember to use lower FGF and to turn the FGF down for the maintenance of anesthesia. Although the decrease in average FGF didn't reach the $20 \%$ goal set, continued reinforcement and delivery of the evidence-based practice recommendations for sevoflurane should continue to occur and to be reinforced. The first bi-annual repetition with an update of project progress 
was presented at department grand rounds again at 1 week short of 6 months from the initial presentation. Recommended continued reinforcement and education had been cited by previous investigators as a potential way to create a lasting practice change (Gupta \& Datta, 2020; Kennedy et al., 2019; Lethbridge et al., 2007; Ryu et al., 2011; A. Singh et al., 2019; P. Singh et al., 2014; Tyagi et al., 2014). In this project, it appears continued efforts created a continued decline in average FGF, and these efforts are continuing in the department. 


\section{References}

American Association of Colleges of Nursing. (2006). The essentials of doctoral education for advanced nursing practice. https://www.aacn.nche.edu./publications/position/DNPEssential

Agency for Healthcare Research and Quality. (2013). Module 10. Academic detailing as a quality improvement tool. https://www.ahrq.gov/ncepr/tools/pf-handbook/mod10.html

Avorn, J. (2017). Academic Detailing: "marketing" the Best Evidence to Clinicians. Journal of the American Medical Association, 317(4), 361-362. DOI: 10.1001/jama.2016.16036

Bonnel, W., \& Smith, K. (2018). Proposal writing for clinical nursing and DNP projects. Springer Publishing.

Cote, C. L. (2019). A Practice of Anesthesia for Infants and Children (6 $6^{\text {th }}$ ed.). Elsevier.

Gupta, A., \& Datta, P. (2020). Sevoflurane consumption during inhalational induction in Children: A randomized comparison of minute ventilation-based techniques with standard fixed fresh gas flow technique. Journal of the American Association of Nurse Anesthetists, 177-181.

Kennedy, R., French, R., Vesto, G., Hanrahan, J., \& Page, J. (2019). The effect of fresh gas flow during induction of anesthesia on sevoflurane usage: A quality improvement study. Anaesthesia, 875882.

Lethbridge, M., Bouckley, A., \& Chambers, N. A. (2007). Patterns of sevoflurane use in a children's hospital: The effects of a simple educational intervention. Anaesthesia and Intensive Care, 35(4), 550-557. https://ncbi.nlm.nih.gov/pubmed/18020074 
MacNeill, A., Lillywhite, R., \& Brown, C. (2017). The impact of surgery on global climate: A carbon footprinting study of operating theatres in three health systems. The Lancet Planetary Health, 381-388.

Petiprin, A. (2016, June 26). Nursing Theory. https://nursingtheory.org/theories-and-models/lewinchange-theory.php

Polit, D., Beck, C. (2017). Nursing research generating and assessing evidence for nursing practice $\left(10^{\text {th }}\right.$ ed.). Wolters Kluwer.

Prielipp, R. (2010). An anesthesiologist's perspective on inhaled anesthesia decision-making. American Journal of Health System Pharmacy, s13-s19.

Ryu, H. G., Lee, J. H., Lee, K. K., Gil, N. S., Kim, C. S., Sim, S. E., . . Min, S. W. (2011). The effect of low fresh gas flow rate on sevoflurane consumption. Korean Journal of Anesthesiology, 60(2), 75-77. https://ncbi.nlm.nih.gov/pmc/articles/pmc3049885

Sherman, J., Le, C., Lamers, V., \& Eckelman, M. (2012, May). Life cycle greenhouse gas emissions of anesthetic drugs. Anesthesia and Analgesia, 114(5), 1086-90. doi:10.1213/ANE.0b013e31824f6940

Singh, A., Sinha, R., Aravindan, A., Kumar, K., \& Datta, P. (2019). Comparison of low-fresh gas flow technique to standard technique of sevoflurane induction in children-A randomized controlled trial. Pediatric Anesthesia, 29(4), 304-309. https://doi.org/10.1111/pan.13582

Singh, P. M., Trikha, A., Sinha, R., Rewari, Ramachandran, R., \& Borle, A. (2014). Sevoflurane induction procedure: cost comparison between fixed $8 \%$ versus incremental techniques in pediatric patients. Journal of the American Association of Nurse Anesthetists, 82(1), 32.

https://ncbi.nlm.nih.gov/pubmed/24654350 
Taylor-Powell, E., \& Renner, M. (2009). Collecting Evaluation Data: End-of-session Questionnaires. University of Wisconsin Extension, Cooperative Extension. Cooperative Extension Publishing. Collecting Evaluation Data: End-of-Session Questionnaires - The Learning Store (wisc.edu)

Tyagi, A., Venkateswaran, V., \& Verma, U. (2014). Cost analysis of three techniques of administering sevoflurane. Anesthesiology Research and Practice, 459432. https://doi.org/10.1155/2014/459432

Warren, J., McLaughlin, M., Bardsley, J., Eiche, J., Esche, C., Kropkowski, L., \& Risch, S. (2016). The strengths and challenges of implementing EBP in healthcare systems. Worldviews on EvidenceBased Nursing, 13(1), 15-24. doi: 10.1111/wvn.12149

West Virginia University Medicine. (2020, June). WVU Medicine. Retrieved from WVUMedicine.org: https://wvumedicine.org/about/leadership-and-more/mission-andvision/ 
Table 1

Sevoflurane EBP Administration

\begin{tabular}{|c|c|c|c|c|c|c|}
\hline Author/date & $\begin{array}{c}\text { Purpose \& } \\
\text { Variables }\end{array}$ & Design/Method & Sample/Setting & Data Analysis & Findings & Appraisal \\
\hline $\begin{array}{l}\text { Gupta \& } \\
\text { Datta, } 2020\end{array}$ & $\begin{array}{l}\text { Comparison to } \\
\text { determine } \\
\text { best method } \\
\text { for induction } \\
\text { with the least } \\
\text { Sevoflurane } \\
\text { waste; Three } \\
\text { methods of } \\
\text { inhalational } \\
\text { induction; } \\
\text { Variables } \\
\text { were time to } \\
\text { intubation \& } \\
\text { sevoflurane } \\
\text { consumption; } \\
\text { Also time to } \\
\text { loss of eyelash } \\
\text { reflex, IV } \\
\text { placement, } \\
\text { LMA insertion; } \\
\text { Incidence of } \\
\text { airway } \\
\text { complication, } \\
\text { tachycardia, } \\
\text { movement, } \\
\text { use of rescue } \\
\text { dose of } \\
\text { propofol. }\end{array}$ & $\begin{array}{l}\text { Parallel } \\
\text { Randomized } \\
\text { Controlled } \\
\text { Trial; After } \\
\text { informed } \\
\text { consent } \\
\text { obtained, each } \\
\text { child randomly } \\
\text { assigned to a } \\
\text { group } \\
\text { (standard } \\
\text { induction, } \\
\text { minute volume } \\
\text { induction, or } \\
\text { 0.5-minute } \\
\text { volume } \\
\text { induction). } \\
\text { Subjects } \\
\text { excluded for } \\
\text { recent URI, } \\
\text { Airway } \\
\text { anomalies, } \\
\text { significant } \\
\text { pulmonary, } \\
\text { cardiac, } \\
\text { neurologic, } \\
\text { obesity, or } \\
\text { genetic } \\
\text { disorders. }\end{array}$ & $\begin{array}{l}45 \text { Children } \\
\text { weighing } \\
\text { between } 10 \mathrm{~kg} \\
\& 20 \mathrm{~kg} \\
\text { undergoing } \\
\text { same day } \\
\text { surgery in a } \\
\text { hospital in } \\
\text { India }\end{array}$ & $\begin{array}{l}\text { SPSS software } \\
\text { used; } \\
\text { Kruskall- } \\
\text { Wallis test } \\
\text { used to } \\
\text { compare time } \\
\text { to intubation } \\
\text { \& sevo } \\
\text { consumption; } \\
\text { Mann- } \\
\text { Whitney used } \\
\text { to analyze } \\
\text { significant } \\
\text { differences in } \\
\text { Kruskall- } \\
\text { Wallis test; P } \\
\text { value .017 } \\
\text { was found to } \\
\text { be significant; } \\
\text { ANOVA } \\
\text { compared } \\
\text { heart rates; } \\
\text { Complications } \\
\text { evaluated } \\
\text { using X2 and } \\
\text { Fisher exact } \\
\text { test }\end{array}$ & $\begin{array}{l}\text { For pediatric } \\
\text { cases using } \\
\text { sevoflurane } \\
\text { for induction, } \\
\text { FGF at half } \\
\text { minute } \\
\text { volume } \\
\text { provided } \\
\text { similar } \\
\text { anesthetic } \\
\text { conditions } \\
\text { for LMA } \\
\text { insertion } \\
\text { with } \\
\text { minimum } \\
\text { sevoflurane } \\
\text { consumption }\end{array}$ & $\begin{array}{l}\text { In pediatric } \\
\text { same day } \\
\text { surgery } \\
\text { patients, using } \\
\text { FGF of half the } \\
\text { patient's } \\
\text { minute volume } \\
\text { for induction is } \\
\text { adequate for } \\
\text { pediatric same } \\
\text { day surgery } \\
\text { cases and } \\
\text { provide the } \\
\text { least amount of } \\
\text { sevoflurane } \\
\text { waste }\end{array}$ \\
\hline
\end{tabular}




\begin{tabular}{|c|c|c|c|c|c|c|}
\hline Author/date & $\begin{array}{c}\text { Purpose \& } \\
\text { Variables }\end{array}$ & Design/Method & Sample/Setting & Data Analysis & Findings & Appraisal \\
\hline $\begin{array}{l}\text { Kennedy et } \\
\text { al., } 2019\end{array}$ & $\begin{array}{l}\text { Determination } \\
\text { of the impact } \\
\text { of FGF used } \\
\text { during } \\
\text { induction of } \\
\text { overall FGF \& } \\
\text { sevoflurane } \\
\text { consumption } \\
\text { during the } \\
\text { case; } \\
\text { Determine the } \\
\text { impact of an } \\
\text { intervention } \\
\text { for staff on } \\
\text { decreasing } \\
\text { FGF to lower } \\
\text { sevo waste; } \\
\text { Variables are } \\
\text { FGF rates } \\
\text { during } \\
\text { induction, FGF } \\
\text { rates for } \\
\text { cases, } \\
\text { consumption } \\
\text { of sevoflurane }\end{array}$ & $\begin{array}{l}\text { Quasi- } \\
\text { experimental } \\
\text { before and } \\
\text { after; Data } \\
\text { collected over } \\
11 \text { months, } \\
\text { three before } \\
\text { and two } \\
\text { months } \\
\text { immediately } \\
\text { after } \\
\text { departmental } \\
\text { reinforcement } \\
\text { (emails, phone } \\
\text { calls) to reduce } \\
\text { FGF use, and } \\
\text { the next six } \\
\text { months } \\
\text { following the } \\
\text { two-month } \\
\text { date collection } \\
\text { period }\end{array}$ & $\begin{array}{l}\text { Four operating } \\
\text { rooms in a } \\
\text { hospital in } \\
\text { New Zealand; } \\
3199 \text { cases had } \\
\text { data on FGF } \\
\text { anonymously } \\
\text { collected from } \\
\text { anesthesia } \\
\text { machine data }\end{array}$ & $\begin{array}{l}\text { Used } \\
\text { GraphPad } \\
\text { Prism } 7 \text { for } \\
\text { analysis; } \\
\text { Time- } \\
\text { weighted } \\
\text { mean used } \\
\text { for overall } \\
\text { FGF; Kruskall- } \\
\text { Wallis test } \\
\text { used for } \\
\text { comparison } \\
\text { across groups } \\
\text { with Dunn's } \\
\text { multiple } \\
\text { comparison } \\
\text { test to } \\
\text { compare the } \\
\text { baseline } \\
\text { period with } \\
\text { both post- } \\
\text { intervention } \\
\text { periods; } \\
\text { Linear } \\
\text { regression } \\
\text { used to show } \\
\text { relationship } \\
\text { between FGF } \\
\text { and sevo use }\end{array}$ & $\begin{array}{l}\text { FGF rates } \\
\text { used during } \\
\text { induction } \\
\text { significantly } \\
\text { impact over } \\
\text { FGF rates and } \\
\text { sevoflurane } \\
\text { consumption; } \\
\text { Staff } \\
\text { intervention } \\
\text { can make an } \\
\text { impact on } \\
\text { FGF } \\
\text { rates/sevo } \\
\text { use but it } \\
\text { may rebound } \\
\text { after the } \\
\text { intervention }\end{array}$ & $\begin{array}{l}\text { FGF rates at } \\
\text { induction affect } \\
\text { overall FGF } \\
\text { rates } \\
\text { significantly and } \\
\text { an intervention } \\
\text { with staff can } \\
\text { lower FGF rates } \\
\text { and sevo use, } \\
\text { but } \\
\text { reinforcement } \\
\text { may be needed } \\
\text { as the changes } \\
\text { may not be } \\
\text { lasting }\end{array}$ \\
\hline
\end{tabular}




\begin{tabular}{|c|c|c|c|c|c|c|}
\hline Author/date & $\begin{array}{c}\text { Purpose \& } \\
\text { Variables }\end{array}$ & Design/Method & Sample/Setting & Data Analysis & Findings & Appraisal \\
\hline & & & & & $\begin{array}{l}\text { decrease in } \\
\text { induction } \\
\text { rooms }\end{array}$ & \\
\hline $\begin{array}{l}\text { Ryu et al., } \\
2011\end{array}$ & $\begin{array}{l}\text { Determining } \\
\text { the impact of } \\
\text { a policy } \\
\text { change aimed } \\
\text { at decreasing } \\
\text { sevoflurane } \\
\text { use and } \\
\text { decreasing } \\
\text { costs; } \\
\text { Variables are } \\
\text { number \& } \\
\text { duration of } \\
\text { anesthesia } \\
\text { cases using } \\
\text { sevo; Number } \\
\text { of sevoflurane } \\
\text { bottles used }\end{array}$ & $\begin{array}{l}\text { Observational } \\
\text { before and } \\
\text { after study; } \\
\text { Amount of } \\
\text { sevoflurane } \\
\text { used was } \\
\text { quantitated } \\
\text { before and } \\
\text { after a policy } \\
\text { change, five } \\
\text { weeks before, } \\
\text { and for the } \\
\text { next three five- } \\
\text { week periods }\end{array}$ & $\begin{array}{l}\text { Twelve } \\
\text { operating } \\
\text { rooms of a } \\
\text { hospital in } \\
\text { Seoul, South } \\
\text { Korea; } 1700 \\
\text { cases reviewed } \\
\text { over } 20 \text {-week } \\
\text { period; Five } \\
\text { weeks before } \\
\text { the policy } \\
\text { change (FGF } \\
\text { equal or less } \\
\text { than } 1 \text { L/min } \\
\text { for anesthesia } \\
\text { maintenance) } \\
\text { and fifteen } \\
\text { weeks after }\end{array}$ & $\begin{array}{l}\text { Direct } \\
\text { comparison } \\
\text { was } \\
\text { performed } \\
\text { with the } \\
\text { extracted } \\
\text { data }\end{array}$ & $\begin{array}{l}\text { Sevoflurane } \\
\text { use } \\
\text { decreased by } \\
\text { almost } 40 \% \\
\text { after a policy } \\
\text { change was } \\
\text { implemented } \\
\text { for staff to } \\
\text { maintain FGF } \\
\text { at equal to or } \\
\text { less than } 1 \\
\text { L/min during } \\
\text { anesthesia } \\
\text { maintenance; } \\
\text { Effects seem } \\
\text { to diminish } \\
\text { over time }\end{array}$ & $\begin{array}{l}\text { Implementing a } \\
\text { policy for } \\
\text { maintaining } \\
\text { sevoflurane FGF } \\
\text { rates at } 1 \mathrm{~L} / \mathrm{min} \\
\text { or less can have } \\
\text { a significant } \\
\text { impact on sevo } \\
\text { consumption in } \\
\text { an anesthesia } \\
\text { department, } \\
\text { but that change } \\
\text { may fade over } \\
\text { time }\end{array}$ \\
\hline $\begin{array}{l}\text { A. Singh et } \\
\text { al., } 2019\end{array}$ & $\begin{array}{l}\text { Determine if } \\
\text { low FGF } \\
\text { during } \\
\text { inhalational } \\
\text { induction with } \\
\text { sevo can } \\
\text { significantly } \\
\text { reduce sevo } \\
\text { consumption } \\
\text { without } \\
\text { adversely } \\
\text { affecting } \\
\text { induction } \\
\text { conditions; } \\
\text { Variables are } \\
\text { amount of } \\
\text { sevo used, } \\
\text { time to loss of } \\
\text { eyelash reflex, } \\
\text { adequate } \\
\text { anesthesia, IV } \\
\text { placement, } \\
\text { and airway } \\
\text { insertion. } \\
\text { Heart rate, } \\
\text { end-tidal }\end{array}$ & $\begin{array}{l}\text { Randomized } \\
\text { Controlled } \\
\text { Trial; After } \\
\text { informed } \\
\text { consent } \\
\text { obtained, } \\
\text { children } \\
\text { between } 1 \text { and } \\
5 \text { yrs. old } \\
\text { undergoing } \\
\text { ophthalmic } \\
\text { procedures } \\
\text { randomized } \\
\text { into one of two } \\
\text { groups } \\
\text { (standard } \\
\text { induction and } \\
\text { low-flow } \\
\text { induction); } \\
\text { Time to } \\
\text { adequate } \\
\text { anesthesia } \\
\text { depth, IV } \\
\text { placement and } \\
\text { air placement } \\
\text { was recorded }\end{array}$ & $\begin{array}{l}\text { Fifty children } \\
\text { undergoing } \\
\text { ophthalmic } \\
\text { procedures at } \\
\text { a hospital in } \\
\text { New Delhi, } \\
\text { India; Subjects } \\
\text { excluded for } \\
\text { cardiac, } \\
\text { neurological, } \\
\text { pulmonary, } \\
\text { genetic } \\
\text { disorders or } \\
\text { anticipated } \\
\text { difficult } \\
\text { airway, IV } \\
\text { access, or for } \\
\text { known allergy } \\
\text { to anesthetics } \\
\text { used }\end{array}$ & $\begin{array}{l}\text { Data were } \\
\text { analyzed } \\
\text { using SPSS } \\
\text { software. } \\
\text { Quantitative } \\
\text { data were } \\
\text { compared } \\
\text { using } \\
\text { unpaired t- } \\
\text { test. } \\
\text { Qualitative } \\
\text { variables } \\
\text { were } \\
\text { compared } \\
\text { using chi- } \\
\text { squared test. } \\
\text { P value of less } \\
\text { than } 0.05 \text { was } \\
\text { considered } \\
\text { significant. }\end{array}$ & $\begin{array}{l}\text { Anesthesia } \\
\text { induction } \\
\text { using low } \\
\text { FGF } \\
\text { significantly } \\
\text { reduces sevo } \\
\text { consumption } \\
\text { without } \\
\text { affecting the } \\
\text { quality of } \\
\text { induction or } \\
\text { increasing } \\
\text { induction } \\
\text { time. }\end{array}$ & $\begin{array}{l}\text { The quality and } \\
\text { efficiency of } \\
\text { induction with } \\
\text { sevoflurane in } \\
\text { children isn't } \\
\text { compromised } \\
\text { using a low FGF } \\
\text { induction } \\
\text { technique }\end{array}$ \\
\hline
\end{tabular}




\begin{tabular}{|c|c|c|c|c|c|c|}
\hline Author/date & $\begin{array}{c}\text { Purpose \& } \\
\text { Variables }\end{array}$ & Design/Method & Sample/Setting & Data Analysis & Findings & Appraisal \\
\hline & $\begin{array}{l}\text { sevoflurane, } \\
\text { and total sevo } \\
\text { consumption. }\end{array}$ & $\begin{array}{l}\text { as were } \\
\text { complicating } \\
\text { events (reflex } \\
\text { tachycardia } \\
\text { heartrate } \\
\text { changes, } \\
\text { rescue } \\
\text { propofol) }\end{array}$ & & & & \\
\hline $\begin{array}{l}\text { P. Singh et } \\
\text { al., } 2014\end{array}$ & $\begin{array}{l}\text { Purpose was } \\
\text { to compare } \\
\text { two } \\
\text { techniques of } \\
\text { sevo } \\
\text { inhalational } \\
\text { induction in } \\
\text { children for } \\
\text { quality and } \\
\text { cost. Variables } \\
\text { are sevo } \\
\text { consumption, } \\
\text { FGF, time to } \\
\text { loss of } \\
\text { consciousness, } \\
\text { IV placement, } \\
\text { and airway } \\
\text { insertion. }\end{array}$ & $\begin{array}{l}\text { Randomized } \\
\text { controlled trial; } \\
\text { After informed } \\
\text { consent } \\
\text { obtained, } \\
\text { children age 1- } \\
8 \text { yrs. were } \\
\text { randomized to } \\
\text { one of two } \\
\text { groups: Group } \\
\text { 1=Fixed } 8 \% \\
\text { induction until } \\
+ \text { LOC vs. Group } \\
2=\text { Incremental- } \\
\text { increase sevo } \\
\text { every three } \\
\text { breaths } \\
\text { starting at } 1 \% \\
\text { group. Times to } \\
+ \text { LOC, IV } \\
\text { placement, and } \\
\text { airway securing } \\
\text { were recorded } \\
\text { as was sevo } \\
\text { usage }\end{array}$ & $\begin{array}{l}\text { One hundred } \\
\text { children } \\
\text { between 1-8 } \\
\text { yrs. without } \\
\text { significant } \\
\text { health } \\
\text { conditions, } \\
\text { having surgery } \\
\text { at a hospital in } \\
\text { India; Subjects } \\
\text { were having } \\
\text { sevoflurane } \\
\text { induction of } \\
\text { anesthesia }\end{array}$ & $\begin{array}{l}\text { Sevo } \\
\text { consumption } \\
\text { calculated } \\
\text { using the } \\
\text { Dion formula. } \\
\text { Data analyzed } \\
\text { with SPSS } \\
\text { software. } \\
\text { Statistical } \\
\text { significance } \\
\text { was set at } \\
\text { 95\%. } \\
\text { Normality of } \\
\text { data verified } \\
\text { using } \\
\text { Kolmogorov- } \\
\text { Smirnov test } \\
\text { and variances } \\
\text { compared } \\
\text { with Leverne } \\
\text { test for } \\
\text { equality of } \\
\text { variance }\end{array}$ & $\begin{array}{l}\text { An } \\
\text { incremental } \\
\text { method of } \\
\text { sevoflurane } \\
\text { induction in } \\
\text { children can } \\
\text { produce } \\
\text { decreases in } \\
\text { sevo usage } \\
\text { and cost } \\
\text { savings. Both } \\
\text { incremental } \\
\text { and fixed } \\
\text { sevo \% } \\
\text { inductions } \\
\text { produce } \\
\text { comparable } \\
\text { safe and } \\
\text { efficient } \\
\text { inductions. }\end{array}$ & $\begin{array}{l}\text { In pediatric } \\
\text { inductions, an } \\
\text { incremental } \\
\text { method of } \\
\text { induction is as } \\
\text { safe and } \\
\text { effective as a } \\
\text { fixed } 8 \% \\
\text { induction and is } \\
\text { more cost and } \\
\text { environmentally } \\
\text { conscientious. }\end{array}$ \\
\hline $\begin{array}{l}\text { Tyagi et al., } \\
2014\end{array}$ & $\begin{array}{l}\text { This study } \\
\text { aims to } \\
\text { evaluate and } \\
\text { compare total } \\
\text { coast of } \\
\text { sevoflurane } \\
\text { and propofol } \\
\text { for } 1 \text { hour of } \\
\text { anesthesia } \\
\text { utilizing three } \\
\text { anesthesia } \\
\text { techniques. }\end{array}$ & $\begin{array}{l}\text { Randomized } \\
\text { controlled trial; } \\
\text { After informed } \\
\text { consent was } \\
\text { obtained, ASA } \\
\text { I-Il adult } \\
\text { patients } \\
\text { undergoing } \\
\text { short duration } \\
\text { elective } \\
\text { surgeries were } \\
\text { randomized to }\end{array}$ & $\begin{array}{l}\text { After informed } \\
\text { consent } \\
\text { obtained forty- } \\
\text { five ASA I-II } \\
\text { adult patients } \\
\text { were } \\
\text { randomized to } \\
\text { one of three } \\
\text { groups; Study } \\
\text { took place in a } \\
\text { hospital in } \\
\text { Delhi, India. }\end{array}$ & $\begin{array}{l}\text { One-way } \\
\text { ANOVA } \\
\text { followed by } \\
\text { Tukey's test } \\
\text { or Dunnett's } \\
\text { T3 used for } \\
\text { comparison } \\
\text { of } \\
\text { quantitative } \\
\text { data among } \\
\text { the groups. } \\
\text { Nominal data }\end{array}$ & $\begin{array}{l}\text { Sevoflurane } \\
\text { only } \\
\text { anesthetics } \\
\text { are superior } \\
\text { to propofol } \\
\text { and } \\
\text { sevoflurane } \\
\text { at two } \\
\text { different low } \\
\text { FGF } \\
\text { techniques. }\end{array}$ & $\begin{array}{l}\text { Lower flow } \\
\text { techniques } \\
\text { shown to use } \\
\text { less } \\
\text { sevoflurane. } \\
\text { Sevoflurane } \\
\text { maintenance } \\
\text { with a propofol } \\
\text { induction is } \\
\text { more cost } \\
\text { effective with a } \\
\text { low flow }\end{array}$ \\
\hline
\end{tabular}




\begin{tabular}{|c|c|c|c|c|c|c|}
\hline Author/date & $\begin{array}{c}\text { Purpose \& } \\
\text { Variables }\end{array}$ & Design/Method & Sample/Setting & Data Analysis & Findings & Appraisal \\
\hline & $\begin{array}{l}\text { Variables are } \\
\text { FGF, +/- } \\
\text { propofol, } \\
\text { sevoflurane } \\
\text { use, }\end{array}$ & $\begin{array}{l}\text { one of three } \\
\text { groups. Group } \\
\text { 1-propofol } \\
\text { induction with } \\
\text { low flow } \\
\text { sevoflurane; } \\
\text { Group 2- } \\
\text { Propofol } \\
\text { induction with } \\
\text { lower flow } \\
\text { sevoflurane; } \\
\text { Group 3-Vital } \\
\text { capacity } \\
\text { sevoflurane } \\
\text { induction and } \\
\text { low flow } \\
\text { sevoflurane } \\
\text { maintenance. }\end{array}$ & $\begin{array}{l}\text { Sevo } \\
\text { vaporizers } \\
\text { were weighed } \\
\text { to calculate } \\
\text { amount used } \\
\text { per case. }\end{array}$ & $\begin{array}{l}\text { analyzed } \\
\text { using chi- } \\
\text { squared test. } \\
\text { Level of } \\
\text { significance } \\
\text { less than } \\
0.05 \text {. }\end{array}$ & & $\begin{array}{l}\text { technique } \\
\text { during } \\
\text { maintenance. }\end{array}$ \\
\hline
\end{tabular}




\section{Table 2}

Descriptive Statistics Procedure Length, Average Fresh Gas Flow, and Minutes to Airway

\begin{tabular}{|c|c|c|c|c|c|}
\hline & & \multicolumn{2}{|c|}{ Descriptives } & \multirow[b]{2}{*}{ Std. Deviation } & \multirow[b]{2}{*}{ Std. Error } \\
\hline & & $\mathrm{N}$ & Mean & & \\
\hline \multirow{4}{*}{$\begin{array}{l}\text { ProcedMin Procedure } \\
\text { length }\end{array}$} & 1 Baseline & 100 & 55.8400 & 38.86254 & 3.88625 \\
\hline & 21-month & 100 & 58.2500 & 40.44759 & 4.04476 \\
\hline & 33-month & 100 & 63.3100 & 42.64457 & 4.26446 \\
\hline & Total & 300 & 59.1333 & 40.66457 & 2.34777 \\
\hline \multirow{4}{*}{ AveFGF Average FGF L/min } & 1 Baseline & 100 & 4.1644 & 1.46715 & .14671 \\
\hline & 21-month & 100 & 3.9436 & 1.76330 & .17633 \\
\hline & 3 3-month & 100 & 3.5365 & 1.29467 & .12947 \\
\hline & Total & 300 & 3.8815 & 1.53787 & .08879 \\
\hline \multirow{4}{*}{$\begin{array}{l}\text { MinToAirway Min to secure } \\
\text { airway }\end{array}$} & 1 Baseline & 100 & 8.0600 & 4.26832 & .42683 \\
\hline & 21-month & 100 & 7.3100 & 5.38178 & .53818 \\
\hline & 33-month & 100 & 6.8700 & 3.46018 & .34602 \\
\hline & Total & 300 & 7.4133 & 4.45293 & .25709 \\
\hline
\end{tabular}




\section{Table 3}

Survey Demographic Data: Provider Type \& Years of Practice

Stub: Q2: I am a(n)

\begin{tabular}{|l|r|r|r|r|r|r|r|}
\hline \multicolumn{1}{|c|}{} & \multicolumn{5}{|c|}{ Q3: I have been administering anesthesia for } \\
\cline { 2 - 7 } & \multicolumn{1}{|c|}{ Total } & $0-2$ years & $3-5$ years & $6-10$ years & $11-15$ years & $16-20$ years & $>20$ years \\
\hline Attending Anesthesiologist & $12.5 \%$ & $0.0 \%$ & $7.1 \%$ & $10.0 \%$ & $15.4 \%$ & $50.0 \%$ & $20.0 \%$ \\
\hline Anesthesiology Resident & $13.9 \%$ & $31.6 \%$ & $28.6 \%$ & $0.0 \%$ & $0.0 \%$ & $0.0 \%$ & $0.0 \%$ \\
\hline Certified Registered Nurse Anesthetist & $65.3 \%$ & $36.8 \%$ & $64.3 \%$ & $90.0 \%$ & $84.6 \%$ & $50.0 \%$ & $80.0 \%$ \\
\hline Student Registered Nurse Anesthetist & $8.3 \%$ & $31.6 \%$ & $0.0 \%$ & $0.0 \%$ & $0.0 \%$ & $0.0 \%$ & $0.0 \%$ \\
\hline Other & $0.0 \%$ & $0.0 \%$ & $0.0 \%$ & $0.0 \%$ & $0.0 \%$ & $0.0 \%$ & $0.0 \%$ \\
\hline
\end{tabular}

Note. Question 1 "Q1" was the consent to take survey with "Q2" and " $\mathrm{Q} 3$ " being provider type and years of experience 


\section{Table 4}

\section{Before and After Survey Response Statistical Comparison}

\section{Paired Samples Test}

\begin{tabular}{|c|c|c|c|c|c|c|c|c|c|c|}
\hline & & & & aired Differ & nces & & & & Signifi & ance \\
\hline & & & Std. & Std. Error & $\begin{array}{r}95 \% \text { Confid } \\
\text { of the D }\end{array}$ & $\begin{array}{l}\text { se Interval } \\
\text { erence }\end{array}$ & & & One- & Two- \\
\hline & & Mean & Deviation & Mean & Lower & Upper & $\mathrm{t}$ & df & Sided $p$ & Sided $p$ \\
\hline Pair & My knowledge of & -1.723 & .910 & .113 & -1.949 & -1.498 & & 64 & $<.001$ & $<.001$ \\
\hline 1 & Sevoflurane's & & & & & & 15.263 & & & \\
\hline & contribution to & & & & & & & & & \\
\hline & environmental & & & & & & & & & \\
\hline & pollution - Before & & & & & & & & & \\
\hline & presentation - My & & & & & & & & & \\
\hline & knowledge of & & & & & & & & & \\
\hline & Sevoflurane's & & & & & & & & & \\
\hline & contribution to & & & & & & & & & \\
\hline & environmental & & & & & & & & & \\
\hline & pollution - After & & & & & & & & & \\
\hline & presentation & & & & & & & & & \\
\hline Pair & My knowledge of & -1.415 & 1.074 & .133 & -1.681 & -1.149 & & 64 & $<.001$ & $<.001$ \\
\hline 2 & how much fresh gas & & & & & & 10.628 & & & \\
\hline & flows impact & & & & & & & & & \\
\hline & Sevoflurane waste - & & & & & & & & & \\
\hline & Before presentation & & & & & & & & & \\
\hline & - My knowledge of & & & & & & & & & \\
\hline & how much fresh gas & & & & & & & & & \\
\hline & flows impact & & & & & & & & & \\
\hline & Sevoflurane waste - & & & & & & & & & \\
\hline & After presentation & & & & & & & & & \\
\hline
\end{tabular}




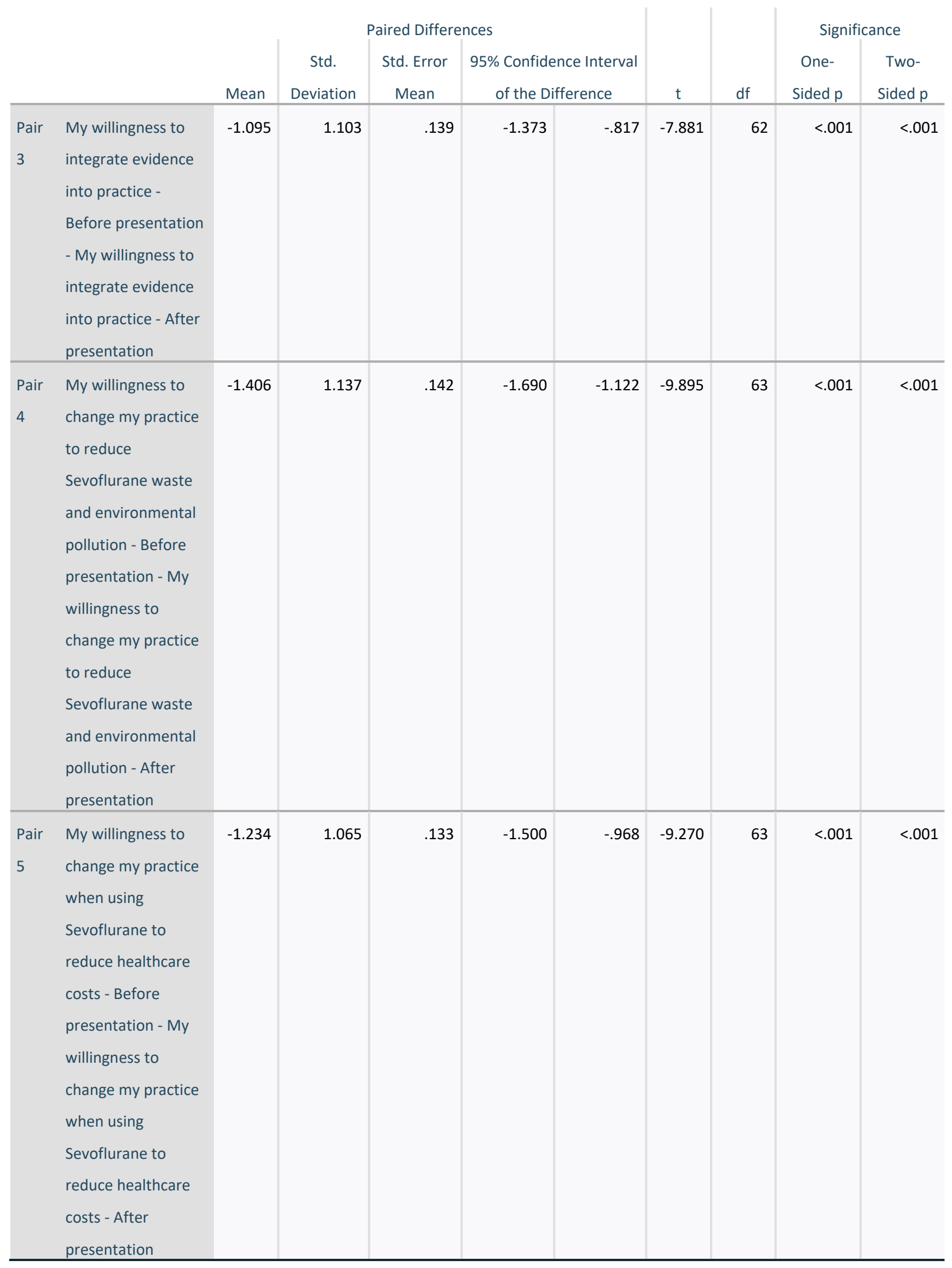


Table 5.

ANOVA Summary Procedure Length, Average Fresh Gas Flow, and Minutes to Airway

\begin{tabular}{|c|c|c|c|c|c|c|}
\hline \multicolumn{7}{|c|}{ ANOVA } \\
\hline & & $\begin{array}{l}\text { Sum of } \\
\text { Squares }\end{array}$ & df & Mean Square & $\mathrm{F}$ & Sig. \\
\hline \multirow{3}{*}{$\begin{array}{l}\text { ProcedMin Procedure } \\
\text { length }\end{array}$} & Between Groups & 2907.087 & 2 & 1453.543 & .878 & .417 \\
\hline & Within Groups & 491521.580 & 297 & 1654.955 & & \\
\hline & Total & 494428.667 & 299 & & & \\
\hline \multirow{3}{*}{$\begin{array}{l}\text { AveFGF Average FGF } \\
\text { பmin }\end{array}$} & Between Groups & 20.291 & 2 & 10.146 & 4.387 & .013 \\
\hline & Within Groups & 686.854 & 297 & 2.313 & & \\
\hline & Total & 707.145 & 299 & & & \\
\hline \multirow{3}{*}{$\begin{array}{l}\text { MinToAirway Min to } \\
\text { secure airway }\end{array}$} & Between Groups & 72.407 & 2 & 36.203 & 1.836 & .161 \\
\hline & Within Groups & 5856.340 & 297 & 19.718 & & \\
\hline & Total & 5928.747 & 299 & & & \\
\hline
\end{tabular}




\section{Table 6}

\section{Tukey's Test Summary for FGF}

\begin{tabular}{|c|c|c|c|c|c|c|c|c|}
\hline \multirow[b]{2}{*}{ Dependent Variable } & & \multirow[b]{2}{*}{$\begin{array}{l}\text { (I) Time Data Collection } \\
\text { timeline }\end{array}$} & \multirow[b]{2}{*}{$\begin{array}{l}\text { (J) Time Data Collection } \\
\text { timeline }\end{array}$} & \multirow{2}{*}{$\begin{array}{c}\text { Mean } \\
\text { Difference (1- } \\
\mathrm{J}) \\
\end{array}$} & \multirow[b]{2}{*}{ Std. Error } & \multirow[b]{2}{*}{ Sig. } & \multicolumn{2}{|c|}{$95 \%$ Confidence Interval } \\
\hline & & & & & & & Lower Bound & Upper Bound \\
\hline \multirow{6}{*}{$\begin{array}{l}\text { ProcedMin Procedure } \\
\text { length }\end{array}$} & \multirow[t]{6}{*}{ Tukey HSD } & \multirow[t]{2}{*}{1 Baseline } & 21-month & -2.41000 & 5.75318 & .908 & -15.9618 & 11.1418 \\
\hline & & & 3 3-month & -7.47000 & 5.75318 & .397 & -21.0218 & 6.0818 \\
\hline & & \multirow[t]{2}{*}{ 21-month } & 1 Baseline & 2.41000 & 5.75318 & .908 & -11.1418 & 15.9618 \\
\hline & & & 3 3-month & -5.06000 & 5.75318 & .654 & -18.6118 & 8.4918 \\
\hline & & \multirow[t]{2}{*}{3 3-month } & 1 Baseline & 7.47000 & 5.75318 & .397 & -6.0818 & 21.0218 \\
\hline & & & 21-month & 5.06000 & 5.75318 & .654 & -8.4918 & 18.6118 \\
\hline \multirow{6}{*}{$\begin{array}{l}\text { MinToAirway Min to } \\
\text { secure airway }\end{array}$} & \multirow[t]{6}{*}{ Tukey HSD } & \multirow[t]{2}{*}{1 Baseline } & 21-month & .75000 & .62799 & .457 & -.7292 & 2.2292 \\
\hline & & & 3 3-month & 1.19000 & .62799 & .142 & -.2892 & 2.6692 \\
\hline & & \multirow[t]{2}{*}{ 21-month } & 1 Baseline & -.75000 & .62799 & .457 & -2.2292 & .7292 \\
\hline & & & 3 3-month & .44000 & .62799 & .763 & -1.0392 & 1.9192 \\
\hline & & \multirow[t]{2}{*}{3 3-month } & 1 Baseline & -1.19000 & .62799 & .142 & -2.6692 & .2892 \\
\hline & & & 21-month & -.44000 & .62799 & .763 & -1.9192 & 1.0392 \\
\hline \multirow{5}{*}{$\begin{array}{l}\text { AveFGF Average FGF } \\
\text { Umin }\end{array}$} & \multirow[t]{5}{*}{ Tukey HSD } & \multirow[t]{2}{*}{1 Baseline } & 21-month & .22080 & .21506 & .561 & -.2858 & .7274 \\
\hline & & & 3 3-month & $.62790^{*}$ & .21506 & .011 & .1213 & 1.1345 \\
\hline & & \multirow[t]{2}{*}{ 21-month } & 1 Baseline & -.22080 & .21506 & .561 & -.7274 & .2858 \\
\hline & & & 3 3-month & .40710 & .21506 & .142 & -.0995 & .9137 \\
\hline & & 3 3-month & 1 Baseline & $-.62790^{*}$ & .21506 & .011 & -1.1345 & -.1213 \\
\hline
\end{tabular}


Figure 1.

Projected Project Timeline

\begin{tabular}{|c|c|c|c|c|c|c|c|c|c|c|c|c|}
\hline Project Phase / Month & $\begin{array}{l}\text { Jul } \\
2020\end{array}$ & $\begin{array}{l}\text { Aug- } \\
\text { Sep }\end{array}$ & $\begin{array}{l}\text { Sep- } \\
\text { Oct }\end{array}$ & $\begin{array}{l}\text { Oct- } \\
\text { Nov }\end{array}$ & $\begin{array}{l}\text { Nov- } \\
\text { Dec }\end{array}$ & $\begin{array}{l}\text { Jan- } \\
\text { Mar } \\
2021\end{array}$ & Apr & Apr & May & May & May & Jun \\
\hline $\begin{array}{l}\text { Project Plan \& } \\
\text { Development }\end{array}$ & & & & & & & & & & & & \\
\hline $\begin{array}{l}\text { Literature Review \& } \\
\text { Evidence Synthesis; } \\
\text { Proposal Draft }\end{array}$ & & & & & & & & & & & & \\
\hline $\begin{array}{l}\text { Departmental \& } \\
\text { Stakeholder } \\
\text { Support; }\end{array}$ & & & & & & & & & & & & \\
\hline $\begin{array}{l}\text { Proposal submission to } \\
\text { Nursing Research } \\
\text { Council and IRB for } \\
\text { approval }\end{array}$ & & & & & & & & & & & & \\
\hline $\begin{array}{l}\text { Pre-intervention Data } \\
\text { Collection/Intervention }\end{array}$ & & & & & & & & & & & & \\
\hline $\begin{array}{l}\text { Baseline \& EBP Survey } \\
\text { Data Collection }\end{array}$ & & & & & & & & & & & & \\
\hline $\begin{array}{l}\text { Month } 1 \text { post- } \\
\text { intervention Data } \\
\text { collection }\end{array}$ & & & & & & & & & & & & \\
\hline $\begin{array}{l}\text { Update Literature } \\
\text { Review }\end{array}$ & & & & & & & & & & & & \\
\hline $\begin{array}{l}\text { Month } 3 \text { post- } \\
\text { intervention Data } \\
\text { collection }\end{array}$ & & & & & & & & & & & & \\
\hline $\begin{array}{l}\text { Data Evaluation, } \\
\text { Analysis, and project } \\
\text { write up }\end{array}$ & & & & & & & & & & & & \\
\hline $\begin{array}{l}\text { Project Presentation } \\
\text { and submision }\end{array}$ & & & & & & & & & & & & \\
\hline
\end{tabular}


Figure 2

Adjusted Project Timeline

\begin{tabular}{|c|c|c|c|c|c|c|c|c|c|c|c|c|}
\hline Project Phase / Month & $\begin{array}{l}\text { Jul } \\
2020\end{array}$ & $\begin{array}{l}\text { Aug- } \\
\text { Sep }\end{array}$ & $\begin{array}{l}\text { Sep- } \\
\text { Oct }\end{array}$ & $\begin{array}{l}\text { Oct- } \\
\text { Nov }\end{array}$ & $\begin{array}{l}\text { Nov- } \\
\text { Dec }\end{array}$ & $\begin{array}{l}\text { Jan- } \\
\text { Mar } \\
2021\end{array}$ & Apr & $\begin{array}{l}\text { May- } \\
\text { Jun }\end{array}$ & $\begin{array}{l}\text { Jul- } \\
\text { Aug }\end{array}$ & Sept & Oct & $\begin{array}{l}\text { Nov- } \\
\text { Dec }\end{array}$ \\
\hline $\begin{array}{l}\text { Project Plan \& } \\
\text { Development }\end{array}$ & & & & & & & & & & & & \\
\hline $\begin{array}{l}\text { Literature Review \& } \\
\text { Evidence Synthesis; } \\
\text { Proposal Draft }\end{array}$ & & & & & & & & & & & & \\
\hline $\begin{array}{l}\text { Departmental \& } \\
\text { Stakeholder } \\
\text { Support; }\end{array}$ & & & & & & & & & & & & \\
\hline $\begin{array}{l}\text { Proposal submission to } \\
\text { Nursing Research } \\
\text { Council and IRB for } \\
\text { approval }\end{array}$ & & & & & & & & & & & & \\
\hline $\begin{array}{l}\text { Pre-intervention Data } \\
\text { Collection/Intervention }\end{array}$ & & & & & & & & & & & & \\
\hline $\begin{array}{l}\text { Baseline \& EBP Survey } \\
\text { Data Collection }\end{array}$ & & & & & & & & & & & & \\
\hline $\begin{array}{l}\text { Month } 1 \text { post- } \\
\text { intervention Data } \\
\text { collection }\end{array}$ & & & & & & & & & & & & \\
\hline $\begin{array}{l}\text { Update Literature } \\
\text { Review }\end{array}$ & & & & & & & & & & & & \\
\hline $\begin{array}{l}\text { Month } 3 \text { post- } \\
\text { intervention Data } \\
\text { collection }\end{array}$ & & & & & & & & & & & & \\
\hline $\begin{array}{l}\text { Data Evaluation, } \\
\text { Analysis, and project } \\
\text { write up }\end{array}$ & & & & & & & & & & & & \\
\hline $\begin{array}{l}\text { Project Presentation } \\
\text { and submission }\end{array}$ & & & & & & & & & & & & \\
\hline
\end{tabular}


Figure 3

Summary of Survey Responses

•

Filters Copy Notes Export $\times$

Summary of My knowledge of Sevoflurane's contribution to environmental pollution

\begin{tabular}{|l|l|l|l|}
\hline Reorder/Recode $\vee$ & Bucketing $\vee$ & Reset \\
\hline
\end{tabular}

My knowledge of Sevoflurane's contribution to environmental pollution

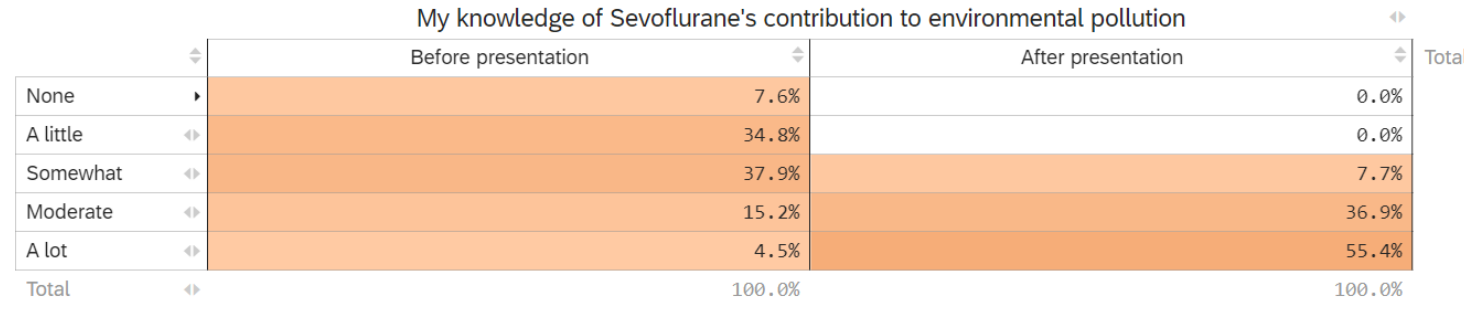




\section{Figure 4}

\section{Summary of Responses}

- 응 My knowledge of how much fresh gas flows impact Sevoflurane waste

Filters Copy Notes Export

Summary of My knowledge of how much fresh gas flows impact Sevoflurane waste

\begin{tabular}{|l|l|l|l|l|}
\hline Reorder/Recode $\vee$ & Bucketing $\vee$ & Reset \\
\hline
\end{tabular} \begin{tabular}{|lll}
\hline & Count & Col \% \\
\hline
\end{tabular}

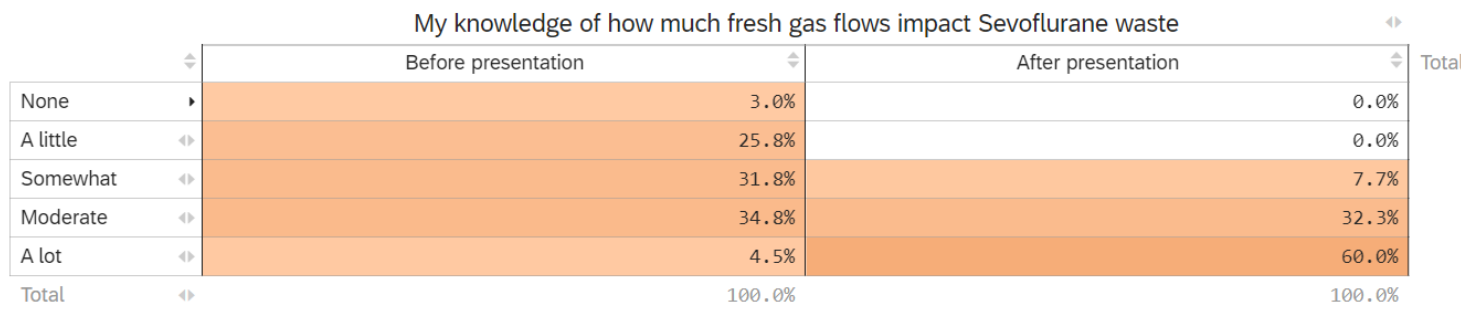


Figure 5

\section{Summary of Responses}

니은 My willingness to integrate evidence into practice

Filters Copy Notes Export $x$

Summary of My willingness to integrate evidence into practice \begin{tabular}{|l|l|l|l|}
\hline Reorder/Recode $\vee$ & Bucketing $\checkmark$ & Reset \\
\hline
\end{tabular} \begin{tabular}{|l|l|l|}
\hline Count & Col \% \\
\hline
\end{tabular}

My willingness to integrate evidence into practice

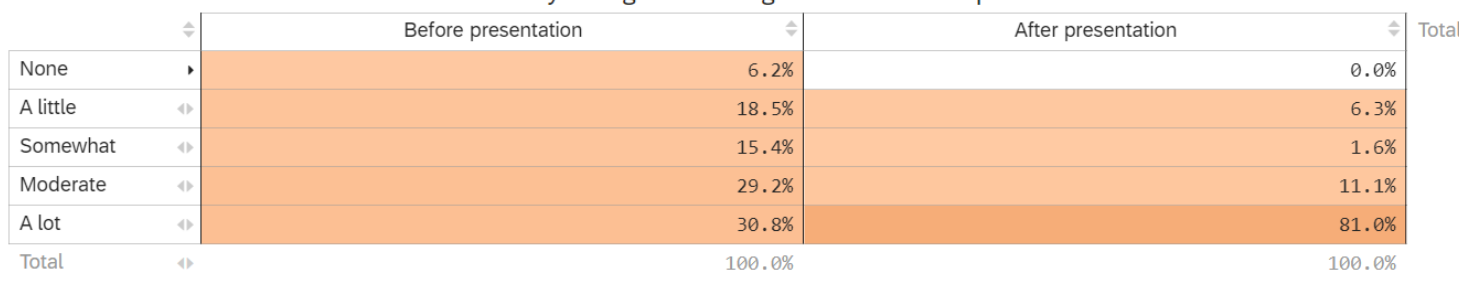


Figure 6

Summary of Responses

Summary of My willingness to change my practice to reduce Sevoflurane waste and environmental pollution \begin{tabular}{|l|l|l|l|}
\hline Reorder/Recode $\vee$ & Bucketing $\checkmark$ & Reset \\
\hline
\end{tabular}

\begin{tabular}{|c|c|c|c|}
\hline & $\Leftrightarrow$ & Before presentation & After presentation \\
\hline None & , & $4.6 \%$ & $0.0 \%$ \\
\hline Somewhat & 4 & $23.1 \%$ & $3.1 \%$ \\
\hline Moderate & 4) & $21.5 \%$ & $10.9 \%$ \\
\hline
\end{tabular}




\section{Figure 7}

\section{Summary of Responses}

Summary of My willingness to change my practice when using Sevoflurane to reduce healthcare costs \begin{tabular}{|l|l|l|l|l|l|l|l|l|l|l|}
\hline Reorder/Recode $\checkmark$ & Bucketing $\vee$ & Reset \\
\hline
\end{tabular}

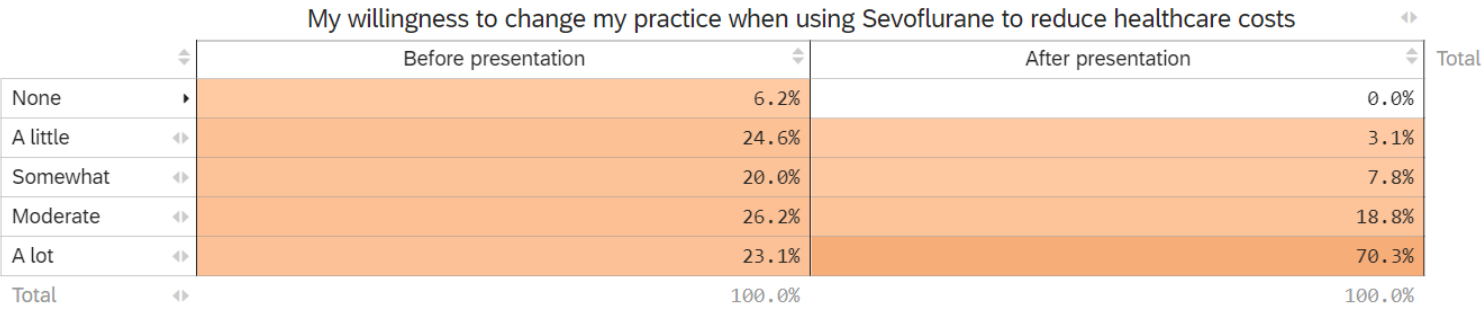


Figure 8

Graphic of Minutes to Airway

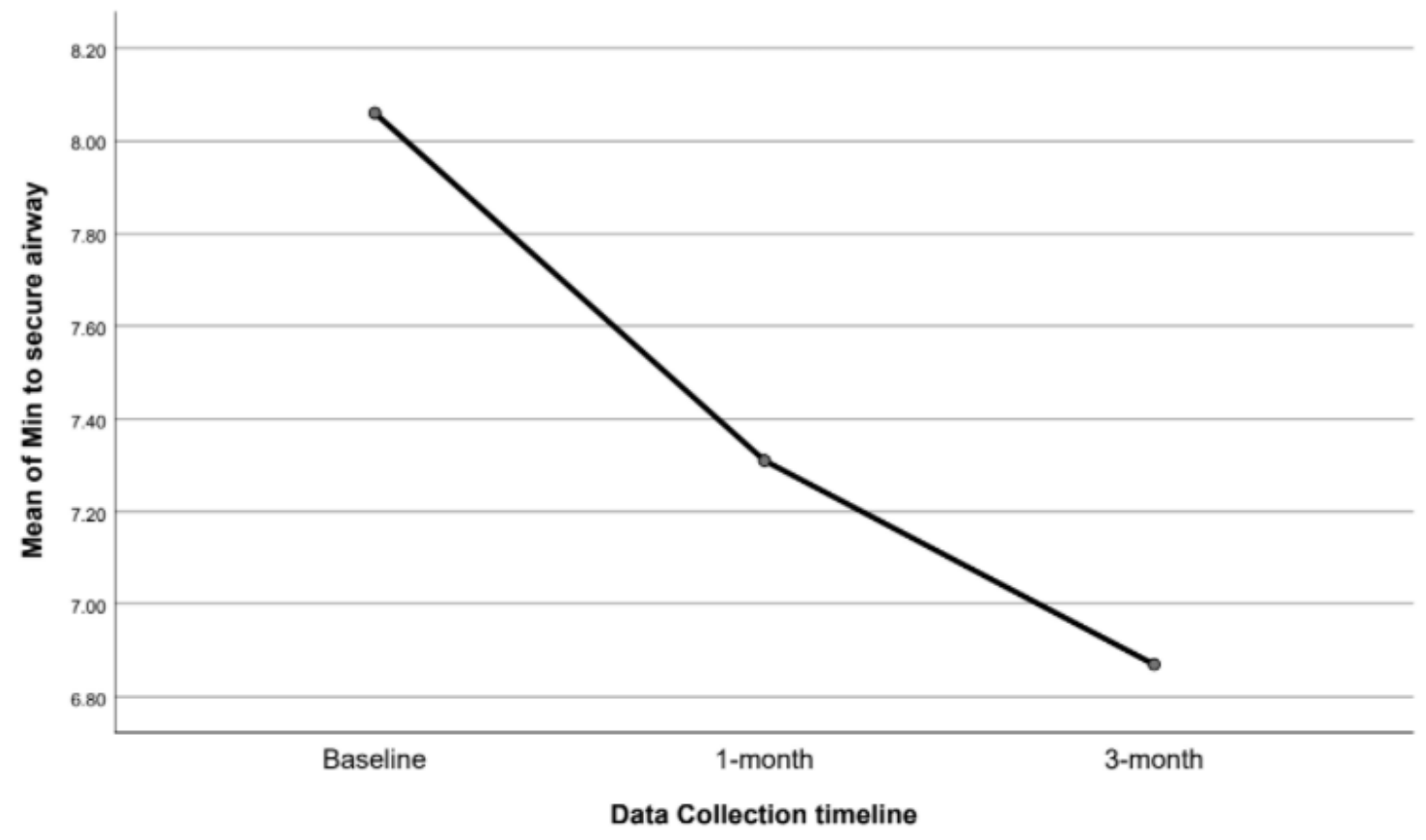


Figure 9

Graphic of Average Fresh Gas Flows

Data Collection timeline

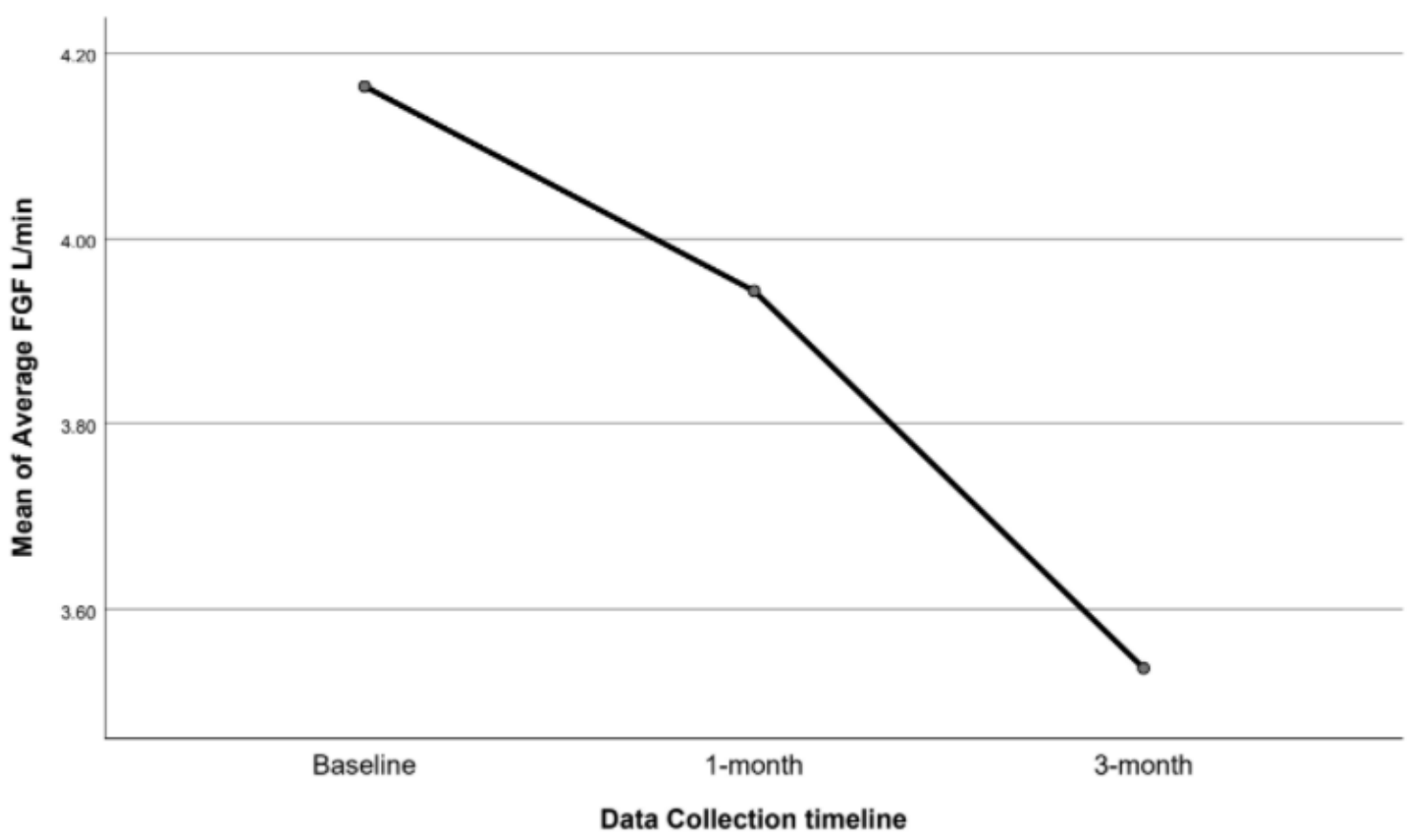


Figure 10

Graphic of Procedure Length

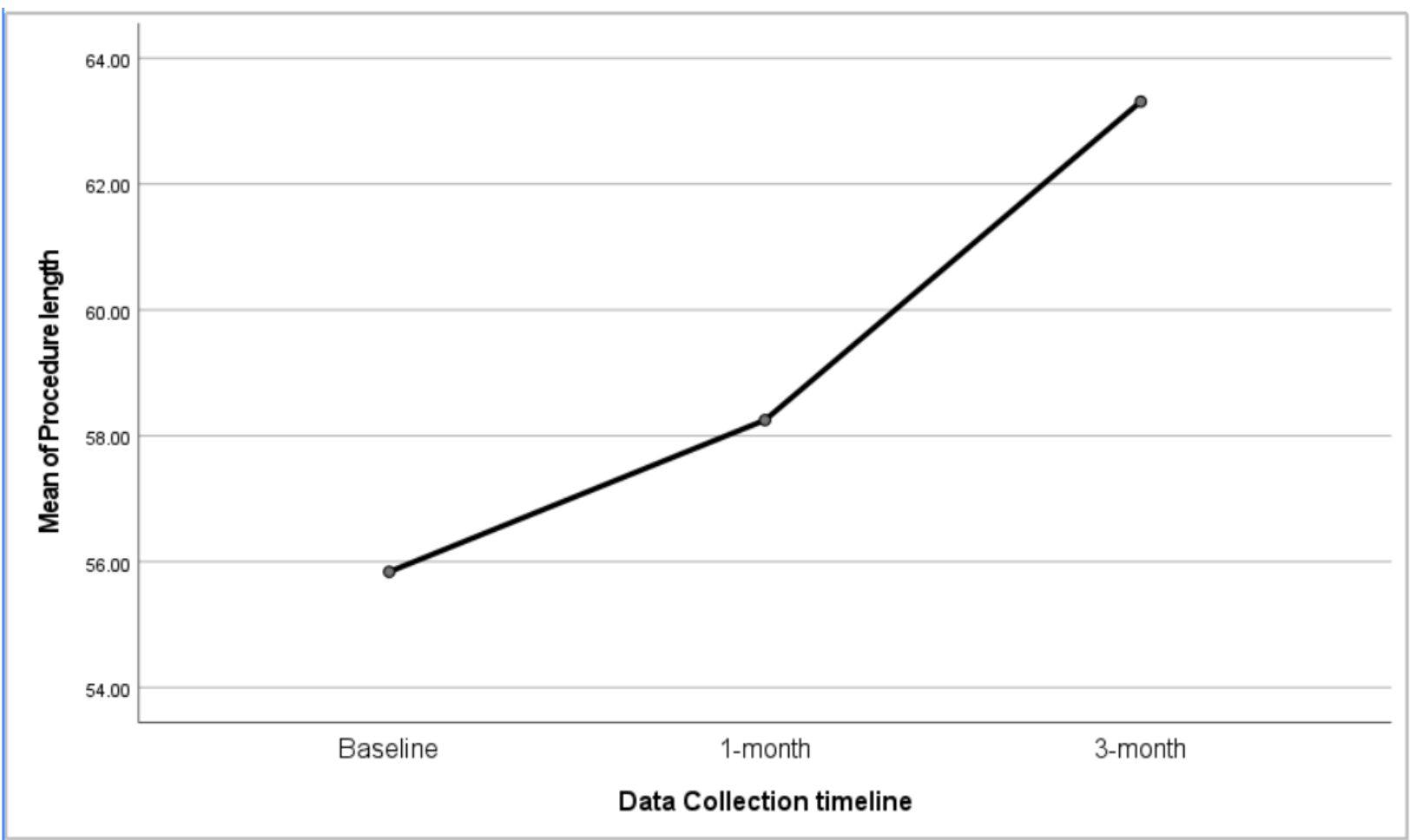




\section{Appendix A}

Educational Program and Pre/Post Educational Survey

\section{SUSTAINABILITY \& \\ INHALATIONAL AGENTS}

WHAT CAN WE DO?

KELLY MEYERS

IRB \# 2012188100

\section{SUSTAINABILITY}

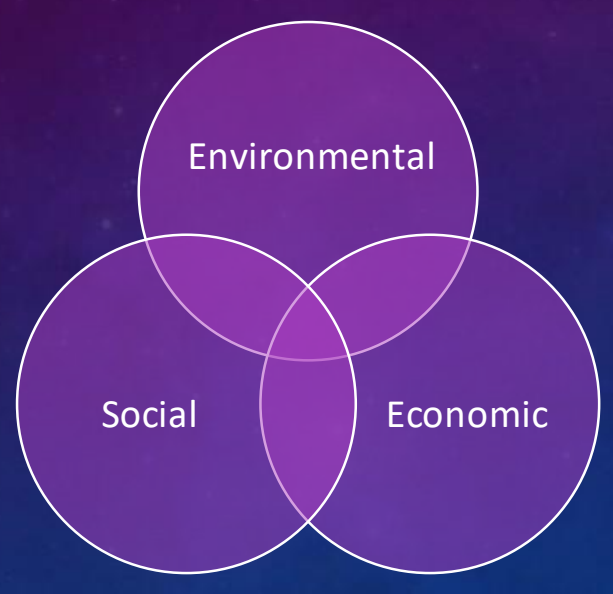




\section{ENVIRONMENTAL CONCERNS}

- Anesthesia gases are not always considered

- Anesthetic contributions are arguably small over all

- Climate goals include $45 \%$ reduction in carbon emissions by 2030

- Waste anesthesia gases are emitted unregulated

- $39 \%$ hospital emissions were from anesthesia

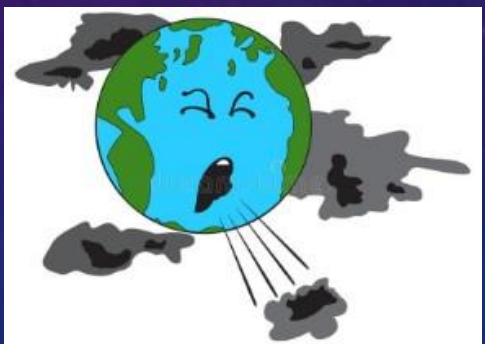
waste gases

\section{WHY SEVOFLURANE?}

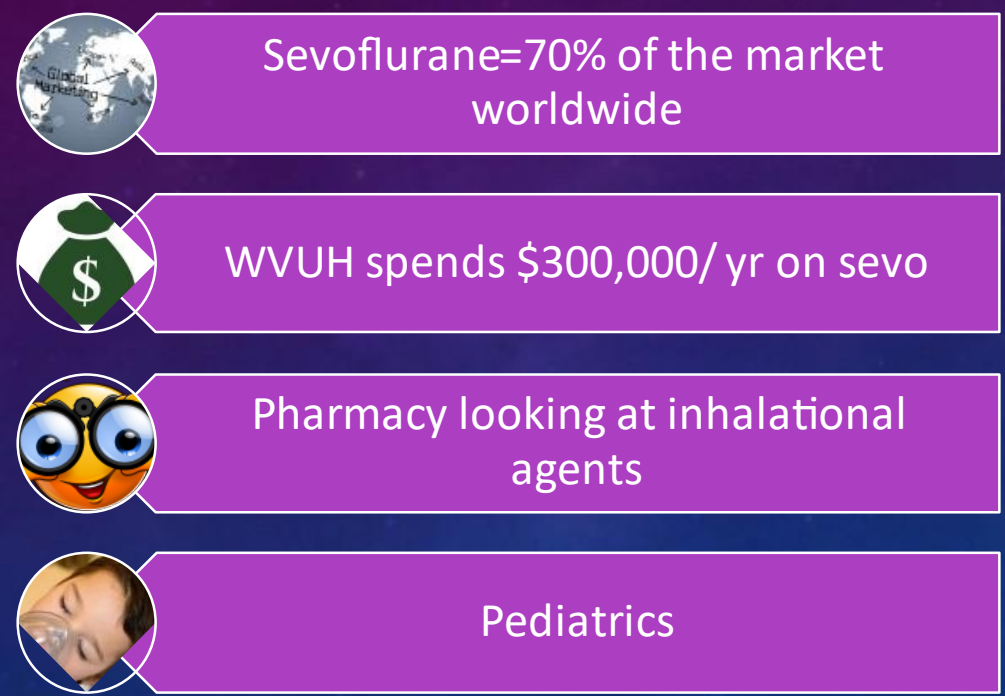


SEVOFLURANE:

HOW DO WE REDUCE OUR WASTE ANESTHESIA GAS?

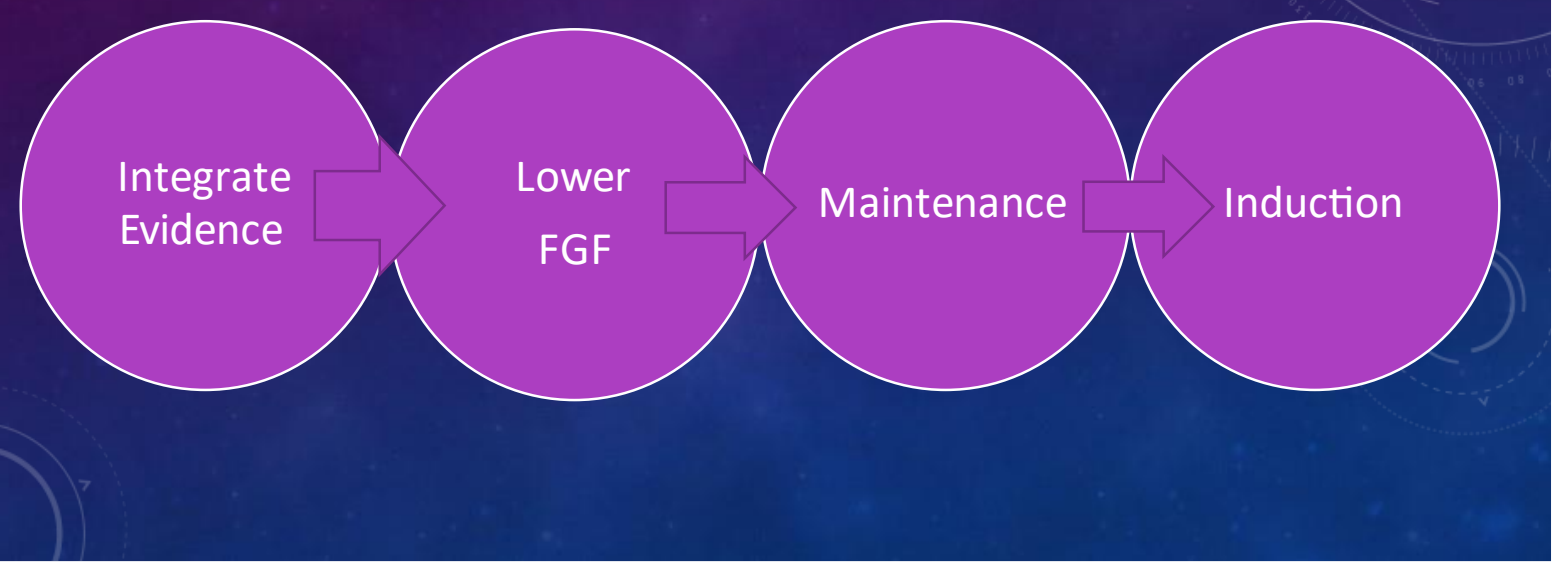

LOOKING FOR SOME DATA.... FOR MAINTENANCE \& INDUCTION

What led to to lower usage?

- Comparison of techniques

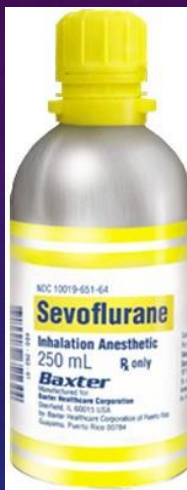

- Before \& After 


\section{INTERVENTIONS...}

\begin{tabular}{|c|c|c|}
\hline Author, yr & Intervention & Reduction \\
\hline $\begin{array}{c}\text { Kennedy et al. } \\
2019\end{array}$ & $\begin{array}{c}\text { Staff education \& } \\
\text { reminders }\end{array}$ & $26 \%$ \\
\hline $\begin{array}{c}\text { Lethbridge, Bouckley, \& } \\
\text { Chambers, } 2007\end{array}$ & $\begin{array}{c}\text { Staff ed. +emails + } \\
\text { phone calls }\end{array}$ & $53 \%$ \\
\hline Ryu et al, 2011 & Policy change (1L/min) & $38 \% *$ \\
\hline
\end{tabular}

\section{SEVOFLURANE INDUCTION \& MAINTENANCE COMPARING TECHNIQUES........}

\begin{tabular}{|l|l|l|}
\hline \multicolumn{1}{|c|}{ Author/yr } & \multicolumn{1}{c|}{ Method } & \multicolumn{1}{c|}{ Result } \\
\hline Tyagi et al, 2014 & $\begin{array}{l}\text { Adults VC induction } \\
\text {.5L/min maintenancevs. prop } \\
\text { induction }\end{array}$ & $\begin{array}{l}\text { Low flows usedleast gas and } \\
\text { cost least wsevo only }\end{array}$ \\
\hline Datta \& Gupta, 2020 & $\begin{array}{l}\text { Prime circuit then 0.5KMV, 1 } \\
\text { xMV, or standard 6L }\end{array}$ & $\begin{array}{l}\text { Safe and effective as standard, } \\
\text { less waste \& cost }\end{array}$ \\
\hline Singh et al, 2019 & $\begin{array}{l}\text { Prime circuit; Dropped flows @ } \\
\text { FM application }\end{array}$ & $\begin{array}{l}\text { Equivalent conditions; Less } \\
\text { WAG's }\end{array}$ \\
\hline
\end{tabular}




\section{USING LOWER FLOWS}

\section{Benefits:}

- Conserves heat and moisture

- Lower flows reduce the amount of

waste anesthesia gases

- Lower flows increase anesthesia

providers' pharmacoeconomic

accountability

\section{CONCERNS WITH LOW-FLOW ANESTHEISIA}

\section{Compound A}

- There were concerns of renal toxicity assevo reacts with agents in the $\mathrm{CO} 2$ absorbent

- Rate studies show production of compound A that lead to tubular necrosis in rats

- Howeverit was found that human and renal biochemistry differed significantly

- We has an FDA recommendation of $2 \mathrm{~L} / \mathrm{min}$ then $1 \mathrm{~L} / \mathrm{min}$ in $1997 .$.

\section{Overheating}

- Caused by a reaction between desiccated potassium-containing $\mathrm{CO} 2$ absorbent and volatile agent

- CO2 absorbent was modified

- If you are concerned you absorbent is desiccated; change it 


\section{SUGGESTIONS:}

- You can safely use lower fresh gas flow for induction

- Flows can be lowered when you reach 1.0 MAC or after circuit prime ( 3 time constants)

- $6 \mathrm{~L} / \mathrm{min} ; 6 \mathrm{~L} / \mathrm{min}$ prime, then turn down with mask placement; Or inductions with $0.5 \mathrm{MV}$

- Maintenance of anesthesia with sevoflurane can be done with $1 \mathrm{~L} / \mathrm{min}$ FGF

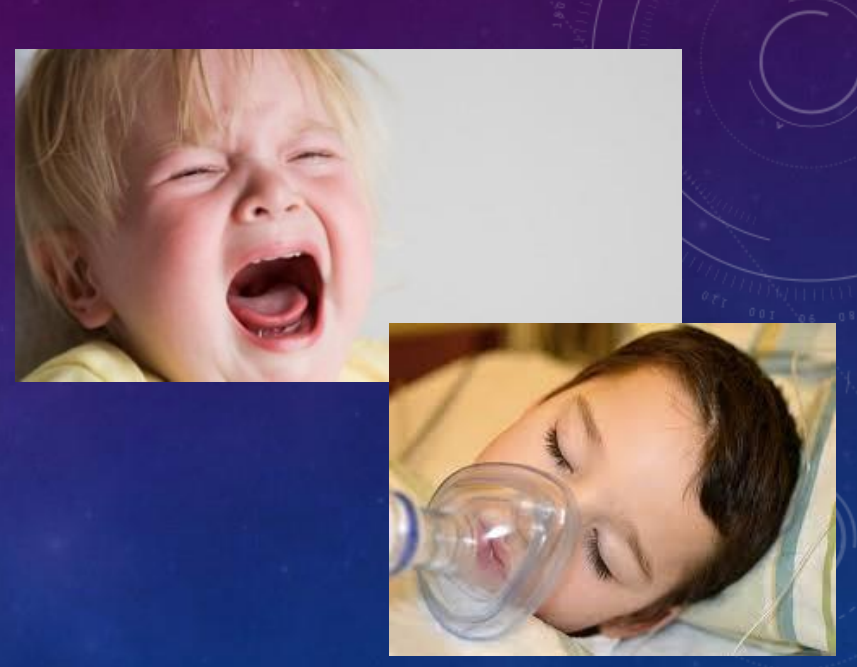

References

Gupta, A., \& Datta, P. (2020). Sevoflurane Consumption During Inhalational Induction in Children: A randomized Comparison of Minute Ventilation-Based Techniques with Standard Fixed Fresh Gas Flow Technique. AANA Journal, 177-181.

Kennedy, R., French, R., Vesto, G., Hanrahan, J., \& Page, J. (2019). The effect of fresh gas flow during induction of anesthesia on sevoflurane usage: a quality improvement study. Anaesthesia, 875-882.

Lethbridge, M., Bouckley, A., \& Chambers, N. A. (2007). Patterns of sevoflurane use in a children's hospital: The effects of a simple educational intervention. Anaesthesia and Intensive Care, 35(4), 550-557. https://ncbi.nlm. nih. gov/pubmed/18020074.

MacNeill, A., Lillywhite, R., \& Brown, C. (2017). The Impact of Surgery on Global Climate: A Carbon Footprinting Study of Operating Theatres in Three Health Systems. The Maciveil, A., Lllywhite, R., \& Brown

Prielipp, R. (2010). An anesthesiologist's perspective on inhaled anesthesia decision -making. American Journal of Health System Pharmacy, s13-s19.

Ryu, H. G., Lee, J. H., Lee, K. K., Gil, N. S., Kim, C. S., Sim, S. E., . . Min, S. W. (2011). The effect of low fresh gas flov rate on sevoflurane consumption. Korean Journal of

Anesthesiology, 60(2), 75-77. https://ncbi.nlm. nih.gov/pmc/articles/pmc3049885

Sherman, J., Le, C., Lamers, V., \& Eckelman, M. (2012, May). Life cycle greenhouse gas emissions of anesthetic drugs. Anesthesia and Analgesia, 114 (5), 1086-90.

doi:10.1213/ANE.0b013e31824f6940

Singh, A., Sinha, R., Aravindan, A., Kumar, K., \&Datta, P. (2019). Comparison of low -fresh gas flow technique to standard technique of sevoflurane induction in children-A randomized controlled trial. Pediatric Anesthesia, 304-309.

Singh, P. M.,Trikha, A., Sinha, R., Rewari, Ramachandran, R., \& Borle, A. (2014). Sevoflurane induction procedure: cost comparison between fixed $8 \%$ versus incremental techniques in pediatric patients. AANA journal, 82 (1), 32. https://ncbi. nlm. nih. gov/pubmed/24654350

Tyagi A., Venkateswaran, V., \&Verma, U. (2014). Cost Analysis of Three Techniques of Administering Sevoflurane. Anesthesiology, 1-12.

Warren, J., McLaughlin, M., Bardsley, J., Eiche, J., Esche, C., Kropkowski, L., \& Risch, S.

(2016). The Strengths and Challenges of Implementing EBP in Healthcare Systems. Worldviews on Evidence -Based Nursing, 15-24. 


\section{PLEASE TAKE SEVO SURVEY!!}

THANK YOU

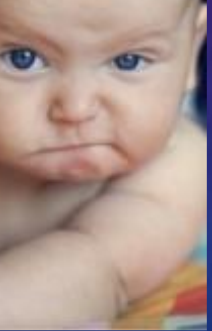

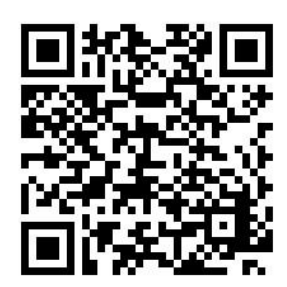


Survey-adapted for Qualtrics:

$\begin{array}{llll}\text { Provider Type (select one): } & \text { Attending } & \text { Resident } & \text { CRNA }\end{array}$

Years of Practice: yrs.

Select the number for answers to questions for both before and after the presentation.

1=none, 2 =a little, $3=$ some(what), 4=moderate, and 5=a lot/very much

1) My knowledge of sevoflurane's contribution to environmental pollution Before

$\begin{array}{lllll}1 & 2 & 3 & 4 & 5\end{array}$

After

$\begin{array}{lllll}1 & 2 & 3 & 4 & 5\end{array}$

2) My knowledge of how much FGF's impact sevoflurane waste

Before

$1 \quad 2 \quad 3 \quad 4 \quad 5$

After

$\begin{array}{lllll}1 & 2 & 3 & 4 & 5\end{array}$

3) My willingness to integrate evidence into practice

$\begin{array}{lllll}\begin{array}{llll}\text { Before } \\ 1\end{array} & 2 & 3 & 4 & 5 \\ \text { After } & & & & \\ 1 & 2 & 3 & 4 & 5\end{array}$

4) My willingness to change my practice to reduce sevoflurane waste and environmental pollution Before

$\begin{array}{lllll}1 & 2 & 3 & 4 & 5\end{array}$

After

$1 \quad 2 \quad 3 \quad 4 \quad 5$

5) My willingness to change my practice when using sevoflurane to reduce healthcare costs Before

$\begin{array}{lllll}1 & 2 & 3 & 4 & 5\end{array}$

After

$\begin{array}{lllll}1 & 2 & 3 & 4 & 5\end{array}$


Appendix B

Data Collection Tool

\begin{tabular}{|c|c|c|c|c|c|c|c|c|c|}
\hline Pt \# & Pt age & $\begin{array}{l}\text { Case } \\
\text { Length } \\
\text { (min) }\end{array}$ & $\begin{array}{l}\text { Time= } \\
\text { Sevo } \\
\text { start }\end{array}$ & $\begin{array}{l}\text { Time= } \\
\text { Airway } \\
\text { secured }\end{array}$ & $\begin{array}{l}\text { Time }= \\
\text { Procedu } \\
\text { re finish }\end{array}$ & $\begin{array}{l}\text { Min to } \\
\text { airway } \\
\text { secure }\end{array}$ & $\begin{array}{l}\text { Total } \\
\text { min } \\
\text { Sevo } \\
\text { use }\end{array}$ & $\begin{array}{l}\text { Average } \\
\text { FGF }\end{array}$ & $\begin{array}{l}\text { Sevo } \mathrm{ml} \\
\text { used }\end{array}$ \\
\hline & & & & & & & & & \\
\hline & & & & & & & & & \\
\hline & & & & & & & & & \\
\hline & & & & & & & & & \\
\hline & & & & & & & & & \\
\hline & & & & & & & & & \\
\hline & & & & & & & & & \\
\hline & & & & & & & & & \\
\hline & & & & & & & & & \\
\hline & & & & & & & & & \\
\hline & & & & & & & & & \\
\hline & & & & & & & & & \\
\hline & & & & & & & & & \\
\hline & & & & & & & & & \\
\hline & & & & & & & & & \\
\hline & & & & & & & & & \\
\hline & & & & & & & & & \\
\hline & & & & & & & & & \\
\hline & & & & & & & & & \\
\hline & & & & & & & & & \\
\hline & & & & & & & & & \\
\hline & & & & & & & & & \\
\hline & & & & & & & & & \\
\hline & & & & & & & & & \\
\hline & & & & & & & & & \\
\hline & & & & & & & & & \\
\hline & & & & & & & & & \\
\hline & & & & & & & & & \\
\hline & & & & & & & & & \\
\hline & & & & & & & & & \\
\hline
\end{tabular}




\section{Appendix C}

\section{Project Support}

From: Cain, James G.

Mer 01, $202011: 22$ AM

o: Meyers, Kelly M.; Lindstrom, Eric J.; Johnstone, Robert E.

Subject: DNP Project

I write in support of Kelly Meyers' Doctor of Nursing Practice project with an aim of reducing sevoflurane waste, expense and environmental impact. The intention of the study is to determine whether an educational program will influence provider behavior. The intervention will be an educational program for the department anesthesiology providers emphasizing rational for reducing delivered fresh gas flows during anesthetics. A review of pre and post intervention electronic medical records will determine whether average fresh gas flows are reduced after an educational program.

Regards,

lames G Cain, MD, MBA, FAAP, D.ABA

jenior Vice Chair and Professor of Anesthesiology

epartment Quality officer

Chief of Pediatric Anesthesiology

304.598.4122

From: Johnstone, Robert E

Sent: Wednesday, September 30, 2020 12:04 PM

To: Meyers, Kelly M.

CC kellylirg@gmail.com
Subject: RE: Doctoral Project

Thanks, Kelly. A nice project. Attached is the study we did here a number of years ago that is relevant to your current study. Bob Johnstone

From: Meyers, Kelly M. <meversk@wnumedicine.org>

Sent: Wednesday, September 30, 2020 11:39 AM

To: Johnstone, Robert E. 〈rejohnstone2@wvumedicine.org〉

Cc: Meyers, Kelly M. <meversk@wvumedicine.org’; kellylirg@gmail.con

Subject: Doctoral Project

Dr. Johnstone,

Thank you for taking the time to discuss with me the doctoral project I am working on regarding reducing sevoflurane waste. Your input and support regarding this project is appreciated. I am sending this email as follow up for verification on the record that I have your approval and support as I move forward with the project.

Thank unu

From: Sizemore, Daniel C.

Sent: Wednesday, September 30, 2020 1:35 PM

To: Meyers, Kelly $\mathrm{M}$.

CC: kellylirgogmail.con

Subject: RE: DNP project

Yes! Please proceed as planned and let me know when the date approaches so I can help with arrangements

Cs

Daniel Chad Sizemore, MD, FASA

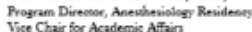

Aavecise Proefasor

sizemoredioguvumerdicine.org 
Appendix D

WVUH and WVU IRB Approvals/Endorsement as NHSR

December 21, 2020

Kelly Meyers

West Virginia University School of Nursing

Morgantown, WV 26506

To the WVU Institutional Review Board

The WVUH Research and Evidence-Based Practice Council supports the research project undertaken by Kelly Meyers, "Sevoflurane: Practice Change Integration Quality Improvement for Pharmacoeconomic Accountability." This is a particularly important project as it has implications that will help to improve the care that patients receive and support the staff that care for them. All necessary resources will be provided to them as they undertake this project. The project outcomes will be used to revise/modify clinician practice as necessary.

The Nursing Research, Evidence-Based Practice and Quality Improvement Council at WVUH grants you permission to complete your project with the following stipulations:

1) Permission is granted based on the project being carried out precisely as defined in your methodology

2) Permission is granted contingent upon approval and/or recommendations of the WVU Institutional Review Board

3) At the mid-point and at the completion of the study, you are requested to share your findings with the Nursing Research and Evidence-Based Council

Please forward me the WVU IRB approval letter for our files.

Best wishes to you in this endeavor!

Cordially,

Lya M. Stroupe

Lya M. Stroupe DNP, APRN, CPNP, NEA-BC, NPD-BC

Manager of Nursing Research and Professional Development/Magnet ${ }^{\circledast}$ Program Director/Transition to Practice

Program Director

Nursing Administration/WVU Medicine

One Medical Center Drive /PO Box 8227

Morgantown, WV 26506-8227

304.293.1417 stroupel@wvumedicine.org 
IRB Protocol Notice: Review Not Required for Protocol 2012188100

(1) You replied on Fri 3/5/2021 5:46 PM

W wvukc@mail.wvu.edu

Fri 3/5/2021 3:48 PM

To: meyersk@mix.wvu.edu; Cotton, Sandra

IRB protocol number: 2012188100

Title: Sevoflurane: Practice Change Integration - A Quality Improvement Study for Pharmacoeconomic Accountability

PI: Sandra L Cotton

The West Virginia University Institutional Review Board reviewed the above-referenced protocol on 5-Mar-2021 and determined that it does not meet the definition of human subject research. To access this protocol, click on the protocol number link provided. Your correspondence concerning this action can be found in the correspondence section $\underline{\mathrm{HERE}}$. Any future protocol action requests can be completed through the WVU+kc system.

NEED HELP? The Office for Human Research Protections is here to assist you from initial submission of a protocol through approval and all subsequent actions. If you have any questions, please contact the Office for Human Research Protections at 304-293-7073 or email IRB@mail.wvu.edu. Thank you.

Please do not reply to this message. Replies to this message are routed to an unmonitored mailbox. If you have questions please use the contact information above. 


\section{Appendix E}

\section{Evaluation Plan}

PICO: In pediatric patients receiving mask inductions at our institution, could the implementation of an EBP educational program on sevoflurane usage for anesthesia providers, compared to the usual routine, decrease the amount of sevoflurane utilized on these cases measured before and after the intervention at one and three months?

\begin{tabular}{|c|c|c|c|c|c|c|}
\hline $\begin{array}{l}\text { Aim(s) } \\
\text { [A purpose or } \\
\text { intention; a } \\
\text { desired outcome] }\end{array}$ & $\begin{array}{l}\text { Outcomes: What you } \\
\text { intend to measure to } \\
\text { evaluate your objective(s) } \\
\text { - your outcome variables - } \\
\text { name them }\end{array}$ & $\begin{array}{l}\text { Objective/Criteria, AEB: } \\
\text { How will you } \\
\text { operationalize the } \\
\text { outcomes? (Or how are } \\
\text { you going to measure } \\
\text { the outcomes?) }\end{array}$ & $\begin{array}{l}\text { Target } \\
\text { Population } \\
\text { [for each } \\
\text { objective] }\end{array}$ & What Data to Collect & $\begin{array}{l}\text { Collection Methods } \\
\text { How is the data } \\
\text { collected? }\end{array}$ & Data Analysis \\
\hline $\begin{array}{l}\text { Project aims to: } \\
\text { 1. Implement an } \\
\text { Educational } \\
\text { Program on } \\
\text { EBP } \\
\text { sevoflurane } \\
\text { use }\end{array}$ & $\begin{array}{l}\text { Feasibility of an educational } \\
\text { intervention on: } \\
\text { 1a. Anesthesia provider } \\
\text { awareness of current } \\
\text { sevoflurane use } \\
\text { 1b. Attitudes toward making } \\
\text { a minor EBP change re } \\
\text { sevoflurane use }\end{array}$ & $\begin{array}{l}\text { 1a. Educational Program } \\
\text { - Lecture/Discussion } \\
\text { - Academic detailing } \\
\text { - Journal Article } \\
\text { 1b. Provide pre/post test } \\
\text { - Knowledge } \\
\text { - Attitudes }\end{array}$ & $\begin{array}{l}\text { Pediatric } \\
\text { Anesthesia } \\
\text { providers }\end{array}$ & $\begin{array}{l}\text { 1a. Basic demographic } \\
\text { data to include type of } \\
\text { provider, (CRNA, } \\
\text { resident, attending, } \\
\text { SRNA), length of } \\
\text { practice } \\
\text { 1b. Educational session } \\
\text { before and after survey } \\
\text { including regarding } \\
\text { knowledge and attitudes } \\
\text { of sevoflurane EBP use }\end{array}$ & $\begin{array}{l}\text { 1a. Demographic data } \\
\text { collected electronically } \\
\text { with post EBP } \\
\text { educational survey } \\
\text { 1b. Test scores from } \\
\text { survey questions } \\
\text { collected }\end{array}$ & $\begin{array}{l}\text { 1a. Demographics } \\
\text { reported in aggregate } \\
\text { using descriptive } \\
\text { statistics } \\
\text { 1b. Test scores } \\
\text { pre/post educational } \\
\text { intervention evaluated } \\
\text { using paired t-test }\end{array}$ \\
\hline $\begin{array}{l}\text { 2. Evaluate the } \\
\text { impact of an } \\
\text { educational } \\
\text { Program on } \\
\text { EBP } \\
\text { sevoflurane } \\
\text { use on } \\
\text { sevoflurane } \\
\text { usage }\end{array}$ & $\begin{array}{l}\text { Increase pharmacoeconomic } \\
\text { accountability of sevoflurane } \\
\text { use. Use of sevoflurane at } 1 \\
\text { month and } 3 \text { months after } \\
\text { project < at baseline } \\
2 \mathrm{a} \text {. Time to airway being } \\
\text { secured at } 1 \text { and } 3 \text { months } \leq \\
\text { baseline } \\
2 \mathrm{~b} \text {. Use of sevoflurane use at } \\
1 \text { and } 3 \text { months < baseline } \\
2 \mathrm{c} \text {. Procedure Length at } \\
\text { baseline, } 1 \text {, and } 3 \text { months }\end{array}$ & $\begin{array}{l}\text { 2a. From 1st minute } \\
\text { sevoflurane identified in } \\
\text { EHR to airway securement } \\
2 \mathrm{~b} \text {. Average FGF fresh gas } \\
\text { flow rates (used to deliver } \\
\text { sevoflurane, correlating } \\
\text { with amount used) data on } \\
\text { first } 100 \text { cases which } \\
\text { match inclusion/exclusion } \\
\text { criteria } \\
2 c \text {. Procedure length from } \\
\text { start to procedure finish in } \\
\text { minutes from EHR }\end{array}$ & $\begin{array}{l}\text { Pediatric } \\
\text { same-day- } \\
\text { surgery } \\
\text { patients }\end{array}$ & $\begin{array}{l}\text { 2a. Minutes to airway } \\
\text { securement after } \\
\text { sevoflurane noted in } \\
\text { record } \\
\text { 2b. Average fresh gas } \\
\text { flow rates (sevoflurane } \\
\text { consumption correlates } \\
\text { with fresh gas flow rates) } \\
\text { FGF rates in included } \\
\text { pediatric cases at } \\
\text { baseline, } 1 \text { month and } 3 \\
\text { months after project } \\
\text { implementation } \\
\text { 2c. Procedue Length in } \\
\text { minutes }\end{array}$ & $\begin{array}{l}\text { 2a. Data collected (min. } \\
\text { to airway securement) } \\
\text { in each case via EHR } \\
\text { 2b. Fresh gas flow rates } \\
\text { correlating with } \\
\text { sevoflurane use from } \\
\text { EHR } \\
\text { 2c. Procedure Length in } \\
\text { minutes from EHR }\end{array}$ & $\begin{array}{l}\text { 2. Mean minutes to } \\
\text { airway will be compared } \\
\text { using ANOVA } \\
\text { 2b. Mean FGF will be } \\
\text { compared using } \\
\text { ANOVA; Estimate } \\
\text { savings on sevoflurane } \\
\text { if statistically different } \\
\text { 2c. Mean procedure } \\
\text { length compared using } \\
\text { ANOVA }\end{array}$ \\
\hline
\end{tabular}

